\title{
A Review of Head Injury and Impact Biomechanics in Recreational Skiing and Snowboarding
}

\author{
D. A. Patton ${ }^{1,2,3}$, A. S. Mclntosh ${ }^{4,5}$, B. E. Hagel2,6,7,8, T. Krosshaug ${ }^{1}$ \\ 1 Oslo Sports Trauma Research Centre (OSTRC), Norwegian School of Sports Sciences, Oslo, Norway \\ 2 Sport Injury Prevention Research Centre (SIPRC), University of Calgary, Calgary, AB, Canada \\ 3 Center for Injury Research and Prevention, Children's Hospital of Philadelphia, Philadelphia, PA, United States \\ ${ }_{4}$ School of Engineering and ACRISP, Edith Cowan University, Joondalup, WA, Australia \\ 5 Mclntosh Consultancy and Research, Cremorne, NSW, Australia \\ 6 Departments of Pediatrics and Community Health Sciences, Cumming School of Medicine, University of \\ Calgary, Calgary, AB, Canada \\ 7 Alberta Children's Hospital Research Institute, University of Calgary, Calgary, AB, Canada \\ ${ }^{8}$ O'Brien Institute for Public Health, University of Calgary, Calgary, AB, Canada
}

\section{CORRESPONDING AUTHOR:}

Declan A. Patton

Sport Injury Prevention Research Centre (SIPRC)

University of Calgary

2500 University Dr NW

Calgary, AB, Canada

E-mail: declan.patton@ucalgary.ca

DOI:

10.32098/mltj.02.2020.07

LEVEL OF EVIDENCE: 5

\section{SUMMARY}

Background. Skiing and snowboarding are popular competitive and recreational sports with associated head injury risks from impact hazards. Understanding head injury hazards and risks in snow sports can inform injury prevention measures, such as helmets, education and environment design of runs and terrain park features, to manage injury risk.

Aim. To identify and discuss (a) the proportion and incidence of head injuries and effectiveness of helmets, (b) circumstances, situational events and characteristics of head injuries and (c) head impact biomechanics in recreational skiing and snowboarding.

Methods. A narrative literature review was performed.

Results. Head injuries comprise up to $38 \%$ and $29 \%$ of all injuries in skiing and snowboarding, respectively. Skull fractures were found to comprise nearly half of all moderate to severe head injuries in alpine sports across all studies. The most common intracranial injury in skiing and snowboarding was cerebral contusion and subdural haematoma, respectively. Fatal head injuries in skiing are rare with an incidence of approximately one death per one million skier-visits and less than $1 \%$ of all skiing head injuries resulted in death. The majority of head injuries were sustained by novice and intermediate level skiers and snowboarders during falls on mild or moderate gradient slopes. Head injury cases occurred in terrain parks were more common in snowboarders than skiers. Fall-related head injuries to skiers are typically in the forward direction with an impact to the front of the head, whereas snowboarders fall rearward and impact the occipital region. Helmet use has increased in recent years, but recent studies have observed an unexpected reduction of the protective effect of helmets in skiing and snowboarding. Alpine sports helmet standards require linear drops onto rigid anvils, but the correlation with snow surfaces is unknown and no helmet standard requires an oblique impact test. Significant protective effects of helmets have been found for collisions and falls onto hard snow.

Conclusions. Alpine sport helmet performance standards should more closely reflect the boundary conditions of impacts to skiers and snowboarders associated with head injury. Administrative and engineering controls may also reduce the risk of head injury in skiing and snowboarding.

\section{KEY WORDS}

Head injury; belmet; impact biomechanics; skiing; snowboarding; snow sports 


\section{INTRODUCTION}

Professional skiing and snowboarding are physically demanding sports involving high speeds, large jumps, technical manoeuvres and equipment specific to each event. In contrast, recreational alpine sports encompass a wide range of ages, skill levels, equipment, environments and hazards. Rigorous long-term injury surveillance programs have been established for professional skiing and snowboarding, which have identified the injury profile of professional athletes differs from recreational skiers and snowboarders $(1,2)$. In addition, high-quality footage of crashes during professional skiing and snowboarding events has enabled detailed investigations of head injuries (3-5). Such detailed injury investigations are limited in the recreational setting. Understanding head injuries in alpine sports can inform injury prevention measures, such as helmets, education and environment design of runs and terrain park features, to reduce head injury risk. Therefore, the purpose of the current review is to identify and discuss (a) the proportion and incidence of head injuries and effectiveness of helmets, (b) circumstances, situational events and characteristics of head injuries and (c) head impact biomechanics in recreational skiing and snowboarding.

\section{HEAD INJURIES}

\section{Incidence}

Hentschel et al. (6) estimated the incidences of head injuries as 5 per one million skiers and 4 per one million snowboarders. In contrast, Hagel et al. (7) estimated the incidence as 25.9 and 73.4 head injuries per one million skiers and snowboarders, respectively. Similarly, Corra et al. (8) estimated that there were 36 hospitalisations due to head injury per one million skier-days. In a recent study, Dickson et al. (9) analysed alpine sport injuries in Western Canada from 2008 to 2013 and reported the average head injury incidence as 0.2 per 1000 skier-visits.

Head injuries in skiing and snowboarding comprise 5-38\% and $5-29 \%$ of all injuries, respectively (table I). Several studies have analysed head injuries in skiing and snowboarding from different time periods $(10,11)$. Shealy et al. (10) compared head injuries in 1990, 2000 and 2010, but found no decrease over time. In contrast, another study by Shealy et al. (12), head injuries were found to decline from $8.4 \%$ to $6.8 \%$ of all head injuries over 17 ski seasons. More recently, Sulheim et al. (11) reported that $17.6 \%$ of all injuries in skiing and snowboarding were head inju-

Table I. Head injuries as a percentage of all injuries in skiing and snowboarding.

\begin{tabular}{|c|c|c|c|c|c|c|c|}
\hline \multirow[t]{2}{*}{ Study } & \multirow[t]{2}{*}{ Country } & \multirow[t]{2}{*}{ Years } & \multirow[t]{2}{*}{ Method } & \multirow[t]{2}{*}{ Sport } & \multirow[t]{2}{*}{$\mathbf{n}$} & \multicolumn{2}{|c|}{$\begin{array}{l}\text { Percentage of all } \\
\text { injuries }\end{array}$} \\
\hline & & & & & & Head & Concussion \\
\hline \multirow[t]{2}{*}{ Lipskie (2000)(16) } & \multirow[t]{2}{*}{ Canada } & \multirow[t]{2}{*}{$1996-1997$} & \multirow[t]{2}{*}{ Ski patrol reports } & Ski & 4226 & $8 \%$ & \\
\hline & & & & Snowboard & 2501 & $10 \%$ & \\
\hline $\begin{array}{l}\text { Machold et al. (2000) } \\
\text { (17) }\end{array}$ & Austria & 1996-1997 & $\begin{array}{l}\text { School student } \\
\text { questionnaire }\end{array}$ & Snowboard & 152 & $11 \%$ & $5 \%$ \\
\hline \multirow[t]{2}{*}{ Dohjima et al. (2001)(18) } & \multirow[t]{2}{*}{ Japan } & \multirow[t]{2}{*}{$1988-1997$} & \multirow[t]{2}{*}{ Hospital admissions } & Ski & 4895 & $10 \%$ & \\
\hline & & & & Snowboard & 1776 & $8 \%$ & \\
\hline Drulec et al. (2001)(19) & Canada & 1990-1998 & $\begin{array}{l}\text { Hospital admissions } \\
\text { (paediatric) }\end{array}$ & Snowboard & 118 & $8 \%$ & \\
\hline \multirow{2}{*}{$\begin{array}{l}\text { Federiuk et al. (2002) } \\
\text { (20) }\end{array}$} & \multirow[t]{2}{*}{ USA } & \multirow[t]{2}{*}{$1992-1999$} & \multirow[t]{2}{*}{ State-wide trauma registry } & Ski & 67 & $38 \%$ & \\
\hline & & & & Snowboard & 31 & $29 \%$ & \\
\hline \multirow{2}{*}{$\begin{array}{l}\text { Langran et al. (2002) } \\
(21,22)\end{array}$} & \multirow[t]{2}{*}{ Scotland } & \multirow[t]{2}{*}{$1999-2002$} & \multirow[t]{2}{*}{ Ski patrol reports } & Ski & 1095 & $15 \%$ & $5 \%$ \\
\hline & & & & Snowboard & 567 & $14 \%$ & $5 \%$ \\
\hline \multirow[t]{2}{*}{ Bridges et al. (2003)(23) } & \multirow[t]{2}{*}{ Canada } & \multirow[t]{2}{*}{ 1999-2000 } & \multirow[t]{2}{*}{ Ski patrol reports } & Ski & 823 & $11 \%$ & $11 \%$ \\
\hline & & & & Snowboard & 434 & $14 \%$ & \\
\hline \multirow[t]{2}{*}{ Hagel et al. $(2003)(7)$} & \multirow[t]{2}{*}{ Canada } & \multirow[t]{2}{*}{ 1991-1999 } & \multirow{2}{*}{$\begin{array}{l}\text { Canadian Hospitals Injury } \\
\text { Reporting and Prevention } \\
\text { Program (CHIRPP) } \\
\text { (paediatric) }\end{array}$} & Ski & 5410 & $16 \%$ & \\
\hline & & & & Snowboard & 3177 & $12 \%$ & \\
\hline
\end{tabular}


Table I. Continues

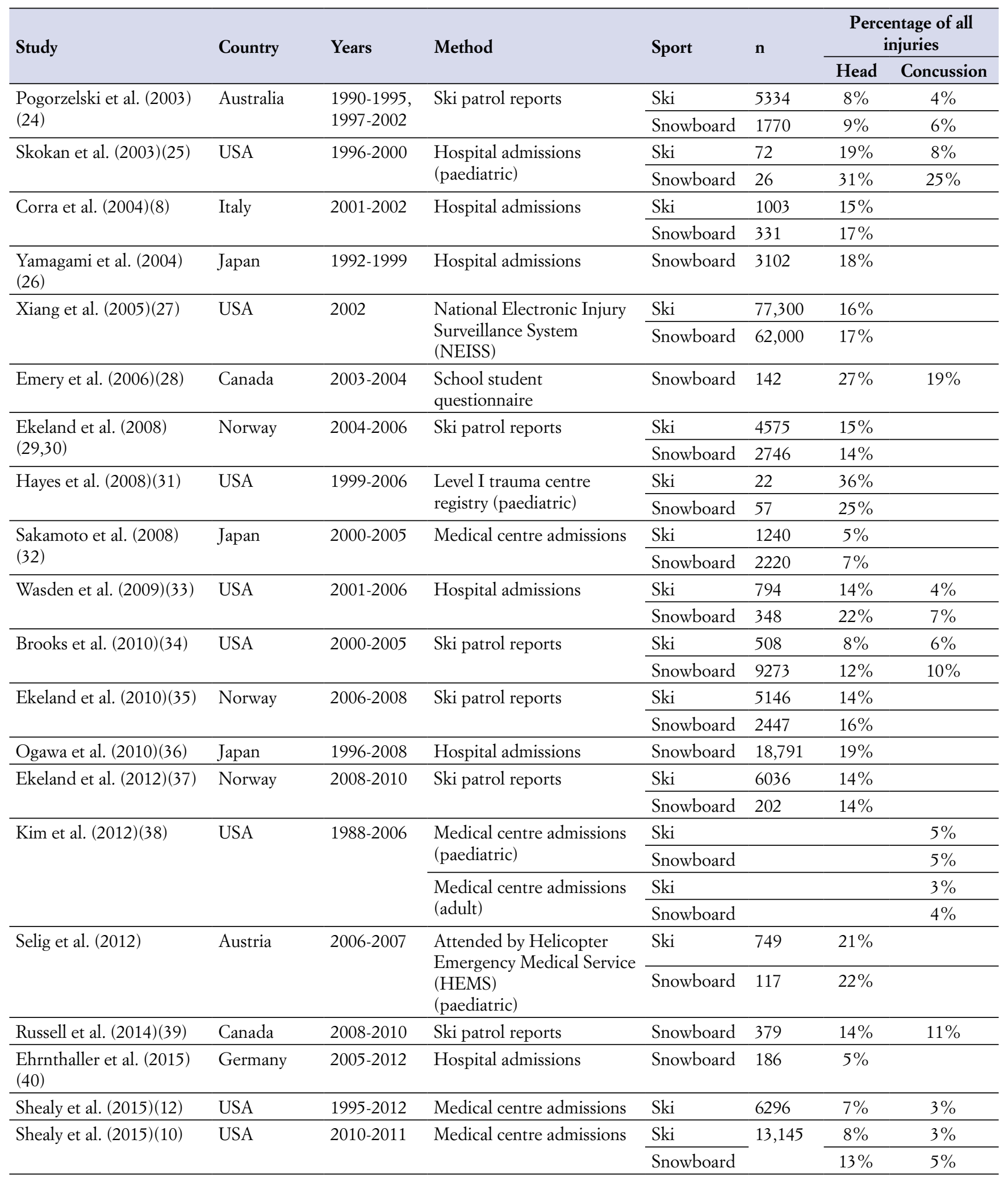


Table I. Continues

\begin{tabular}{|c|c|c|c|c|c|c|c|}
\hline \multirow[t]{2}{*}{ Study } & \multirow[t]{2}{*}{ Country } & \multirow[t]{2}{*}{ Years } & \multirow[t]{2}{*}{ Method } & \multirow[t]{2}{*}{ Sport } & \multirow[t]{2}{*}{$\mathbf{n}$} & \multicolumn{2}{|c|}{$\begin{array}{l}\text { Percentage of all } \\
\text { injuries }\end{array}$} \\
\hline & & & & & & Head & Concussion \\
\hline \multirow[t]{2}{*}{ Stenroos et al. (2015)(41) } & \multirow[t]{2}{*}{ Finland } & \multirow[t]{2}{*}{$2010-2011$} & \multirow[t]{2}{*}{ Ski patrol reports } & Ski & 1991 & $15 \%$ & \\
\hline & & & & Snowboard & 893 & $12 \%$ & \\
\hline \multirow[t]{2}{*}{ Basques et al. (2016)(42) } & \multirow[t]{2}{*}{ USA } & \multirow[t]{2}{*}{ 2011-2012 } & \multirow{2}{*}{$\begin{array}{l}\text { American College of } \\
\text { Surgeons (ACS) National } \\
\text { Trauma Data Bank (NTDB) }\end{array}$} & Ski & 3351 & $20 \%$ & \\
\hline & & & & Snowboard & 2704 & $26 \%$ & \\
\hline \multirow[t]{2}{*}{ Weber et al. (2016)(43) } & \multirow[t]{2}{*}{ Europe } & \multirow[t]{2}{*}{$1993-2012$} & \multirow{2}{*}{$\begin{array}{l}\text { German Trauma Society } \\
\text { Register }\end{array}$} & Ski & 373 & $22 \%$ & \\
\hline & & & & Snowboard & 52 & $25 \%$ & \\
\hline Dickson et al. (2017)(9) & Canada & $2008-2013$ & Ski patrol reports & $\begin{array}{l}\text { Ski, } \\
\text { snowboard }\end{array}$ & 82,124 & $9 \%$ & $8 \%$ \\
\hline \multirow{2}{*}{$\begin{array}{l}\text { Van Laarhoven et al. } \\
(2017)(44)\end{array}$} & \multirow{2}{*}{$\begin{array}{l}\text { The } \\
\text { Netherlands }\end{array}$} & \multirow[t]{2}{*}{$2012-2014$} & \multirow[t]{2}{*}{ Hospital admissions } & Ski & 232 & $13 \%$ & \\
\hline & & & & Snowboard & 411 & $11 \%$ & \\
\hline \multirow[t]{2}{*}{ Summers et al. (2017)(45) } & \multirow[t]{2}{*}{ Australia } & \multirow[t]{2}{*}{$2005-2015$} & \multirow{2}{*}{$\begin{array}{l}\text { Ski patrol reports } \\
\text { (paediatric) }\end{array}$} & Ski & 3821 & $7 \%$ & \\
\hline & & & & Snowboard & 2422 & $6 \%$ & \\
\hline \multirow[t]{2}{*}{ Basques et al. (2018)(46) } & \multirow[t]{2}{*}{ USA } & \multirow[t]{2}{*}{$2011-2012$} & \multirow{2}{*}{$\begin{array}{l}\text { American College of } \\
\text { Surgeons (ACS) National } \\
\text { Trauma Data Bank (NTDB) }\end{array}$} & Ski & 3351 & $20 \%$ & \\
\hline & & & & Snowboard & 2704 & $26 \%$ & \\
\hline \multirow[t]{2}{*}{ Ekeland et al. (2019)(47) } & \multirow[t]{2}{*}{ Norway } & \multirow[t]{2}{*}{$2010-2012$} & \multirow[t]{2}{*}{ Ski patrol reports } & Ski & 3569 & $15 \%$ & \\
\hline & & & & Snowboard & 1236 & $13 \%$ & \\
\hline
\end{tabular}

ries. For youth, head injuries in skiing and snowboarding comprise $7-36 \%$ and $6-31 \%$ of all injuries, respectively.

\section{CONCUSSION}

Concussions are currently a head injury of concern in sports (13), particularly skiing and snowboarding as they comprise $3-8 \%$ and $5-25 \%$ of all injuries, respectively (table I). Specifically, concussions represent $31-77 \%$ and $32-83 \%$ of all head injuries in skiing and snowboarding, respectively. The accuracy of the diagnosis of concussions can vary across studies. For example, Shealy et al. (10) found that concussions represented between $6 \%$ and $11 \%$ of all skiing and snowboarding injuries according to ski patrol reports, respectively, but medically diagnosed concussions represented only $3 \%$ and $5 \%$ of all skiing and snowboarding injuries, respectively. In a recent study, Gil et al. (14) reported the incidence of concussion for skiers was 9.8 concussions per one million skier-seasons. The incidence of 12.7 concussions per one million snowboarder-seasons was significantly higher. Gil et al. (14) also reported that the concussion incidence for youth and males was higher than for adults and females, respectively. Similarly, Bergmann et al. (15) reported that youth snowboarders had a greater likelihood of sustaining a concussion compared to youth skiers.

\section{MODERATE TO SEVERE HEAD INJURIES}

Several studies have reported the nature of moderate to severe head injuries in recreational skiing and snowboarding (table II). Across studies, skull fractures comprised 46\% of all moderate to severe head injuries: skiing, 53\%; snowboarding, $40 \%$. Some studies reported types of skull fractures as a proportion of moderate to severe head injuries in skiing and snowboarding: basilar skull fractures, 20-27\%; linear skull fractures, 10-19\%; depression skull fractures, $7 \%(6,48,49)$.

The most common intracranial injury in skiing was cerebral contusion, which was found to comprise $22 \%$ of all moderate to severe head injuries across studies. In contrast, subdural haematoma comprised $27 \%$ of all moderate to severe head injuries in snowboarding across studies. Subarachnoid, epidural and intracerebral haematoma are relatively uncommon in alpine sports comprising $9 \%, 7 \%$ and $2 \%$ of all moderate to severe head injuries across studies, respectively. Interestingly, Levy et al. (48) reported diffuse axonal 
Table II. Moderate to severe head injuries in recreational skiing and snowboarding.

\begin{tabular}{|c|c|c|c|c|c|c|c|c|c|c|c|}
\hline \multirow{2}{*}{ Study } & \multirow{2}{*}{ Country } & \multirow{2}{*}{ Years } & \multirow{2}{*}{ Method } & \multirow{2}{*}{ Sport } & \multicolumn{7}{|c|}{ Moderate-severe head injury } \\
\hline & & & & & $\mathbf{n}$ & Fracture & SDH & SAH & EDH & $\mathrm{ICH}$ & Contusion \\
\hline $\begin{array}{l}\text { Diamond et al. } \\
(2001)(50)\end{array}$ & USA & $\begin{array}{l}1994- \\
1997\end{array}$ & $\begin{array}{l}\text { State-wide TBI } \\
\text { database }\end{array}$ & Ski & 118 & $24 \%$ & & & $39 \%$ & & \\
\hline \multirow{2}{*}{$\begin{array}{l}\text { Fukuda et al. } \\
(2001)(51)\end{array}$} & \multirow[t]{2}{*}{ Japan } & \multirow{2}{*}{$\begin{array}{l}1994- \\
1999\end{array}$} & \multirow{2}{*}{$\begin{array}{l}\text { Hospital } \\
\text { admissions }\end{array}$} & Ski & 46 & $50 \%$ & $11 \%$ & $13 \%$ & $4 \%$ & $2 \%$ & $15 \%$ \\
\hline & & & & Snowboard & 49 & $31 \%$ & $35 \%$ & $10 \%$ & $2 \%$ & $0 \%$ & $16 \%$ \\
\hline $\begin{array}{l}\text { Levy et al. } \\
(2002)(48)\end{array}$ & USA & $\begin{array}{l}1982- \\
1998\end{array}$ & $\begin{array}{l}\text { Trauma centre } \\
\text { registry }\end{array}$ & $\begin{array}{l}\text { Ski }(83 \%), \\
\text { snowboard } \\
(17 \%)\end{array}$ & 265 & $39 \%$ & $9 \%$ & & $9 \%$ & $8 \%$ & $28 \%$ \\
\hline $\begin{array}{l}\text { Nakaguchi et al. } \\
(2002)(52)\end{array}$ & Japan & $\begin{array}{l}1995- \\
2000\end{array}$ & $\begin{array}{l}\text { Hospital } \\
\text { admissions }\end{array}$ & Snowboard & 48 & $15 \%$ & $38 \%$ & $17 \%$ & $6 \%$ & & $21 \%$ \\
\hline \multirow{2}{*}{$\begin{array}{l}\text { Siu et al. (2004) } \\
(49)\end{array}$} & \multirow[t]{2}{*}{ Australia } & \multirow{2}{*}{$\begin{array}{l}1994- \\
2002\end{array}$} & \multirow{2}{*}{$\begin{array}{l}\text { Hospital } \\
\text { admissions }\end{array}$} & Ski & 18 & $39 \%$ & $11 \%$ & $11 \%$ & $6 \%$ & $6 \%$ & $28 \%$ \\
\hline & & & & Snowboard & 10 & $60 \%$ & $10 \%$ & $10 \%$ & $10 \%$ & $0 \%$ & $10 \%$ \\
\hline $\begin{array}{l}\text { Fukuda et al. } \\
(2007,2008) \\
(53,54)\end{array}$ & Japan & $\begin{array}{l}1999- \\
2003\end{array}$ & $\begin{array}{l}\text { Hospital } \\
\text { admissions }\end{array}$ & Snowboard & 88 & $61 \%$ & \multicolumn{5}{|c|}{$39 \%$} \\
\hline $\begin{array}{l}\text { Simson et al. } \\
(2008)(55)\end{array}$ & Canada & $\begin{array}{l}1986- \\
1995 \\
\end{array}$ & Various & Ski & 24 & $29 \%$ & & & & & $23 \%$ \\
\hline \multirow{2}{*}{$\begin{array}{l}\text { Wasden et al. } \\
(2009)(33)\end{array}$} & \multirow[t]{2}{*}{ USA } & \multirow{2}{*}{$\begin{array}{l}2001- \\
2006\end{array}$} & \multirow{2}{*}{$\begin{array}{l}\text { Hospital } \\
\text { admissions }\end{array}$} & Ski & 87 & $29 \%$ & $13 \%$ & $17 \%$ & & & $28 \%$ \\
\hline & & & & Snowboard & 44 & $9 \%$ & $16 \%$ & $18 \%$ & & & $41 \%$ \\
\hline $\begin{array}{l}\text { Fukuda (2011) } \\
\text { (56) }\end{array}$ & Japan & $\begin{array}{l}1992- \\
2007\end{array}$ & $\begin{array}{l}\text { Hospital and } \\
\text { medical centre } \\
\text { admissions }\end{array}$ & Ski & 54 & & $24 \%$ & & $2 \%$ & & $28 \%$ \\
\hline $\begin{array}{l}\text { Corra et al. } \\
(2012)(59)\end{array}$ & Italy & $\begin{array}{l}2001- \\
2005\end{array}$ & $\begin{array}{l}\text { Hospital } \\
\text { admissions }\end{array}$ & $\begin{array}{l}\text { Ski }(88 \%), \\
\text { snowboard } \\
(12 \%)\end{array}$ & 108 & $31 \%$ & $6 \%$ & $17 \%$ & $24 \%$ & & $22 \%$ \\
\hline $\begin{array}{l}\text { Shealy et al. } \\
(2015)(12)\end{array}$ & USA & $\begin{array}{l}1995- \\
2012\end{array}$ & $\begin{array}{l}\text { Medical centre } \\
\text { admissions }\end{array}$ & Ski & 438 & $69 \%$ & & & & & \\
\hline
\end{tabular}

SDH: subdural haematoma. SAH: subarachnoid haematoma. EDH: epidural haematoma. ICH: intracerebral haematoma.

injury comprised $8 \%$ of all moderate to severe head injuries in skiing and snowboarding.

\section{FATAL HEAD INJURIES}

Skiing has long been associated with fatal head injuries 60-64, which includes the deaths of celebrities, such as
Sonny Bono and Natasha Richardson. Although head injury has been identified as the primary cause of death in $41-53 \%$ of all traumatic fatalities occurring on the slopes (65-67), fatal head injuries in skiing are rare with an incidence of approximately one death per one million skier-visits (12). In addition, less than $1 \%$ of all skiing head injuries end in death (12). Coronial inquests have been conducted to inves- 
tigate fatal head injuries in alpine sports in New Zealand (68) and Canada (67).

\section{LIMITATIONS OF PREVIOUS RESEARCH}

There are several limitations associated with previously published research regarding head injuries in skiing and snowboard, most notably the definitions of injuries. The lack of a consistent definition for concussion throughout the literature is well known. The Consensus Statements on Concussion in Sport have attempted to provide a consistent definition for clinicians and researchers (13). In addition, the definition of moderate to severe head injury varies throughout the literature, e.g. positive neuroimaging finding, hospitalisation or simply head injuries that are considered 'non-minor'. Although not specified within studies, it is likely moderate to severe head injuries are defined similar to the Abbreviated Injury Scale (AIS) definitions (69).

Another limitation is the method of data collection, e.g. self-reported questionnaires. Trauma registries and admission records of patients to hospitals and medical centres are considered reliable, but may not contain complete information for each patient. One quarter of studies relied upon ski patrol reports, which have been found to be a reliable source of information on risk factors for skiing and snowboarding compared to follow-up information (70). Lastly, a lack of prospective injury surveillance studies exists, which have been successfully implemented at the professional level $(1,2)$, but is substantially more difficult in a recreational setting.

\section{HELMETS}

At the turn of the century, helmet use in skiing and snowboarding was less than $20 \%(30,71-73)$, which has subsequently increased to over $60 \%$ since $2010(9-11,37,74,75)$. Youth skiers and snowboarders are more likely to wear helmets compared to adults (73). In addition, younger children are more likely to use helmets compared to adolescents $(15,76)$. In 1999, the United States Consumer Product Safety Commission (CPSC) investigated skiing and snowboarding head injuries and concluded that helmets reduce the risk of such injuries (77). Subsequent systematic reviews supported the protective value of helmets in skiing and snowboarding (78-80). Skinner et al. (67) analysed 45 alpine sport-related deaths in Ontario from 1991 to 2012. Of the 25 head injury cases an expert review team determined that a certified helmet would have prevented death in $36 \%$ of cases, probably prevented death in $24 \%$ of cases and possibly prevented death in $16 \%$ cases. In contrast, Baschera et al. (81) found no significant decrease in severe traumatic brain injury among skiers despite an increase in helmet use. Bergmann et al. (15) found no significant difference between concussion incidence for helmeted and non-helmeted youth skiers and snowboarders. Such findings were supported by Milan et al. (82) with helmet use not significantly influencing head injury in youth skiers and snowboarders, but helmeted patients admitted to the ICU had significantly lower head injury severity compared to non-helmeted patients. Sulheim et al. (11) observed an unexpected reduction in the protective effect of helmets in skiing and snowboarding over time. More recently, Porter et al. (83) found helmet use was associated with higher injury severity although helmet users were less likely to sustain a skull fracture. For helmets to reduce the risk of head injury, the mechanisms of head injuries are required to be well understood $(84,85)$.

\section{HEAD IMPACT CHARACTERISTICS}

\section{Demographics}

Studies of head injury in skiing and snowboarding have reported that $58-84 \%$ were male $(6,9,15,48-54,57-59,86$ 94). It is unknown if such a finding is due to skiing and snowboarding being more popular amongst males, whether males engage in higher-energy activities, which may be at or beyond skill capabilities. For head injured skiers and snowboarders, mean ages ranged from 23 to 29 years with the youngest and oldest being 2 and 83 years, respectively $(6,48$ $54,90,92)$. Over $80 \%$ of all cases are sustained by skiers and snowboarders older than 15 years $(59,93)$ and few studies have reported solely on paediatric head injuries in skiing and snowboarding $(15,58,95)$.

Skill levels of head injured skiers and snowboarders have been reported in several studies (table III), but no standardised definitions were used by such studies. The majority of skiing head injuries were sustained by novice (33-50\%) and intermediate (42-45\%) level skiers. Similarly, the majority of snowboarding head injuries were sustained by novice $(31-57 \%)$ and intermediate (26-49\%) level snowboarders. Only $8-23 \%$ and $5-19 \%$ of head injuries were sustained by advanced level skiers and snowboarders, whereas recent studies of head injured skiers and snowboarders reported that $28-38 \%$ and had an advanced skill level.

\section{INCIDENT LOCATION}

Several studies have reported the incident location of recreational skiing and snowboarding head injury cases (table IV). The majority of head injuries occurred on slopes (62-97\%), which have mild and moderate gradients. Although few 
Table III. Skill level of recreational skiing and snowboarding head injury cases.

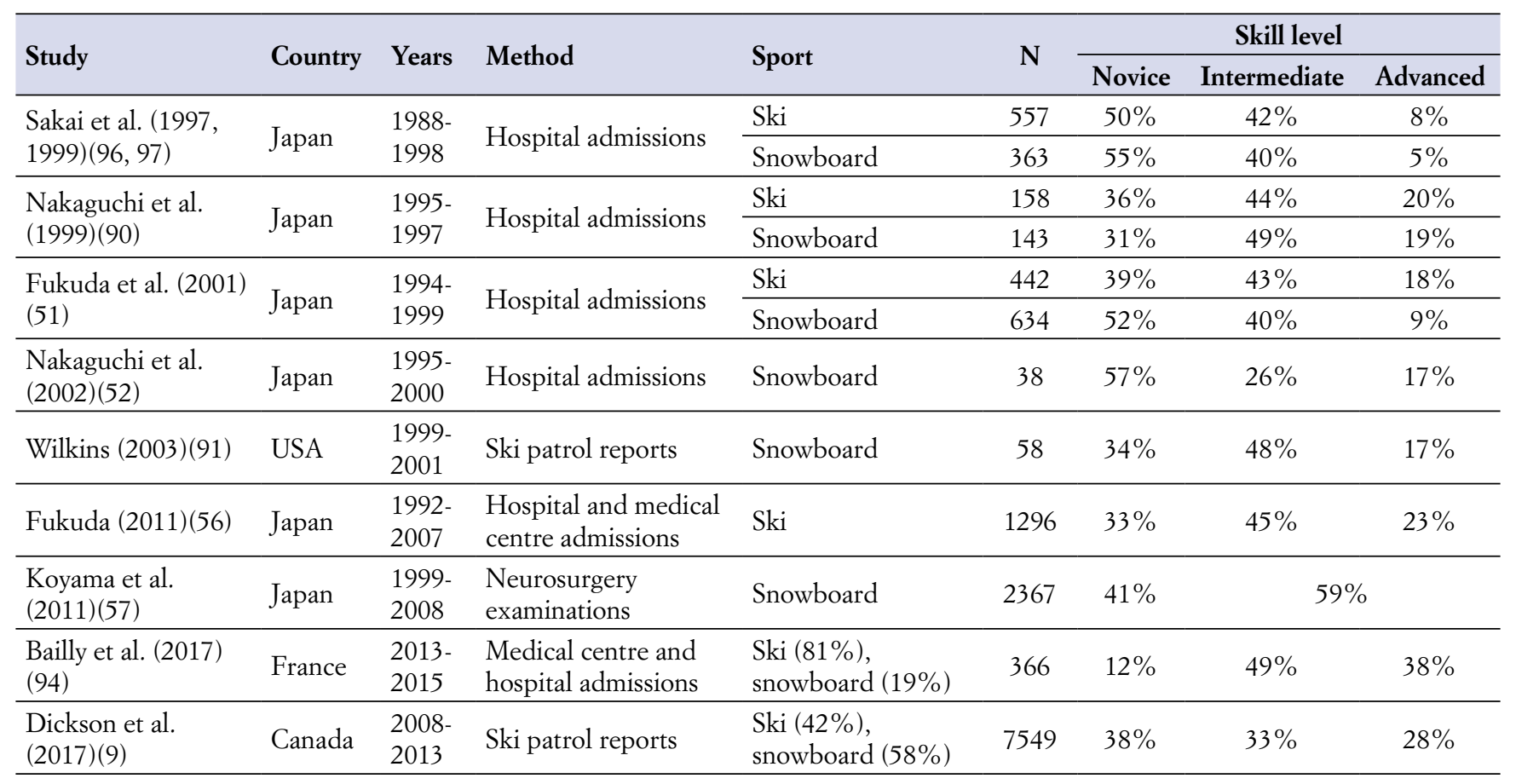

Table IV. Incident location of recreational skiing and snowboarding head injury cases.

\begin{tabular}{|c|c|c|c|c|c|c|c|c|c|}
\hline \multirow[b]{2}{*}{ Study } & \multirow[b]{2}{*}{ Country } & \multirow[b]{2}{*}{ Years } & \multirow[b]{2}{*}{ Method } & \multirow[b]{2}{*}{ Sport } & \multirow[b]{2}{*}{$\mathbf{N}$} & \multicolumn{3}{|c|}{ Slope } & \multirow[b]{2}{*}{$\begin{array}{c}\text { Terrain } \\
\text { park }\end{array}$} \\
\hline & & & & & & $\begin{array}{c}\text { Mild } \\
\left(<10^{\circ}\right)\end{array}$ & $\begin{array}{c}\text { Moderate } \\
\left(10-20^{\circ}\right)\end{array}$ & $\begin{array}{l}\text { Steep } \\
\left(>20^{\circ}\right)\end{array}$ & \\
\hline $\begin{array}{l}\text { Sakai et al. } \\
(1997,1999) \\
(96,97)\end{array}$ & Japan & $\begin{array}{l}1988- \\
1998\end{array}$ & $\begin{array}{l}\text { Hospital } \\
\text { admissions }\end{array}$ & Snowboard & 363 & $39 \%$ & $48 \%$ & $13 \%$ & \\
\hline $\begin{array}{l}\text { Machold et al. } \\
(2000)(17)\end{array}$ & Austria & $\begin{array}{l}1996- \\
1997 \\
\end{array}$ & $\begin{array}{l}\text { School student } \\
\text { questionnaire }\end{array}$ & Snowboard & 17 & & $74 \%$ & & \\
\hline \multirow{2}{*}{$\begin{array}{l}\text { Fukuda et al. } \\
(2001)(51)\end{array}$} & \multirow[t]{2}{*}{ Japan } & \multirow{2}{*}{$\begin{array}{l}1994- \\
1999\end{array}$} & \multirow{2}{*}{$\begin{array}{l}\text { Hospital } \\
\text { admissions }\end{array}$} & Ski & 442 & $35 \%$ & $51 \%$ & $12 \%$ & $3 \%$ \\
\hline & & & & Snowboard & 634 & $33 \%$ & $29 \%$ & $6 \%$ & $31 \%$ \\
\hline $\begin{array}{l}\text { Nakaguchi et al. } \\
(2002)(52)\end{array}$ & Japan & $\begin{array}{l}1995- \\
2000\end{array}$ & $\begin{array}{l}\text { Hospital } \\
\text { admissions }\end{array}$ & Snowboard & 38 & $41 \%$ & $30 \%$ & $0 \%$ & $30 \%$ \\
\hline $\begin{array}{l}\text { Fukuda et al. } \\
(2007,2008) \\
(53,54)\end{array}$ & Japan & $\begin{array}{l}1999- \\
2003\end{array}$ & $\begin{array}{l}\text { Hospital } \\
\text { admissions }\end{array}$ & Snowboard & 1190 & & & & $38 \%$ \\
\hline $\begin{array}{l}\text { Moffat et al. } \\
(2009)(100)\end{array}$ & USA & $\begin{array}{l}2006- \\
2007 \\
\end{array}$ & $\begin{array}{l}\text { Level I trauma } \\
\text { centre registry }\end{array}$ & Ski, snowboard & 94 & & & & $26 \%$ \\
\hline \multirow{2}{*}{$\begin{array}{l}\text { Brooks et al. } \\
(2010)(34)\end{array}$} & \multirow[t]{2}{*}{ USA } & \multirow{2}{*}{$\begin{array}{l}2000- \\
2005\end{array}$} & \multirow{2}{*}{$\begin{array}{l}\text { Ski patrol } \\
\text { reports }\end{array}$} & Ski & 443 & & & & $24 \%$ \\
\hline & & & & Snowboard & 1133 & & & & $45 \%$ \\
\hline $\begin{array}{l}\text { Ruedl et al. } \\
(2010)(93)\end{array}$ & Austria & $\begin{array}{l}2008- \\
2009\end{array}$ & $\begin{array}{l}\text { Ski patrol } \\
\text { reports }\end{array}$ & $\begin{array}{l}\text { Ski }(78 \%) \text {, } \\
\text { snowboard }(22 \%)\end{array}$ & 277 & $37 \%$ & $54 \%$ & $9 \%$ & $0 \%$ \\
\hline
\end{tabular}


Table IV. Continues

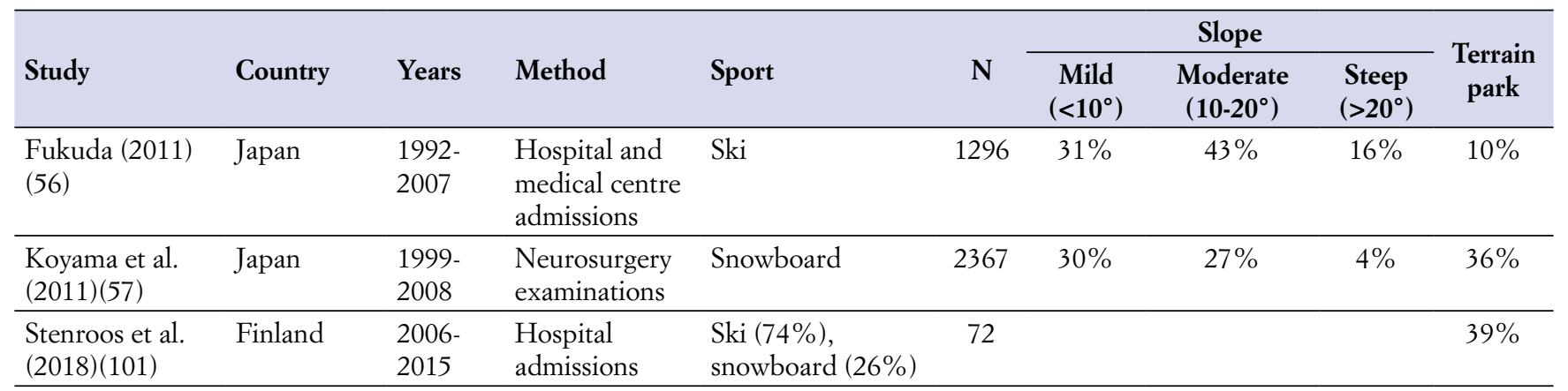

Note: Moffat et al. (100) reported head/face injuries. Ruedl et al. (93) classified slopes as per the European piste classification system (102).

injuries occurred on steep slopes, relatively more head injuries occurring on steep slopes were reported for skiing (9-16\%) compared to snowboarding (0-6\%). Ruedl et al. (98) investigated the factors associated with injuries occurring on slope intersections and found no significant difference between the proportion of head/neck injuries sustained on slope intersections $(12.3 \%)$ compared to general slopes $(12.4 \%)$. For skiing, less than $25 \%$ of all head injury cases were reported to have occurred in terrain parks, whereas $30-45 \%$ of all snowboarding head injury cases occurred in terrain parks. Head injuries in skiing and snowboarding as a proportion of all injuries have been found to be greater in terrain parks compared to slopes $(34,98-100)$.

In terms of the skill level of head injured snowboarders, Nakaguchi et al. (52) reported that all novices were on mild slopes. In contrast, almost all head injured intermediate and advanced snowboarders were on moderate slopes (89\%). Koyama et al. (57) reported that $54 \%$ of head injured novice snowboarders were on mild slopes and $62 \%$ of all head injured intermediate and advanced snowboarders were on moderate or steep slopes.

Few studies reported the condition of the snow for head injury cases $(52,93,103)$ Sakai et al. $(103)$ reported that the snow was 'packed' or 'ice and debris' for skiing and snowboarding in $56 \%$ and $64 \%$ of cases, respectively. More recent studies have reported that the snow was 'hard' and 'iced' for $75 \%$ of head injury cases in skiing and snowboarding, whereas the snow was 'soft' in only $25 \%$ of cases (52,93).

\section{SITUATIONAL EVENT}

In terms of gross biomechanical description (104), several studies have reported the situational event of recreational skiing and snowboarding head injury cases (table V). Most head injuries in skiing are sustained during falls (36-74\%) followed by collisions (20-62\%), whereas fewer head injuries were sustained during jumps $(1-31 \%)$. The majority of snowboarding head injuries are sustained during falls $(38-63 \%)$ followed by jumps (14-38\%) and collisions $(10-29 \%)$.

\section{FALLS}

Burtscher et al. (109) investigated the predictors of falls in skiing and snowboarding with younger age and alcohol consumption reported as risk factors. Similarly, Konik et al. (110) investigated fall-related head injuries and identified that skiers and snowboarders younger than 40 years were most affected and had the most severe intracranial lesions and/or skull fractures. The fall incidence of fall-related head injuries as 0.2 per 1000 skier-days. More recently, Philippe et al. (111) found that younger age and lower skills were predictive of skiing and snowboarding falls. In addition, soft snow conditions and alcohol consumption were found to be predictors for falls in skiing and snowboarding, respectively. The incidence of falls was identified as 0.08 and 0.43 per hour for skiing and snowboarding, respectively, which was substantially lower than data collected a decade prior (109). Phillippe et al. (111) attributed the decrease in fall incidence to improvements in skiing and snowboarding equipment and slope preparation. Stenroos et al. (101) reported $90 \%$ of falls by skiers and snowboarders that resulted in head injury occurred on slopes and the remaining $10 \%$ occurred in the terrain park.

Few studies have reported the direction of fall for skiers and snowboarders. For skiers, Nakaguchi et al. (90) reported that falls causing head injuries were most commonly in the forward direction $(54 \%)$, followed by the rearward $(35 \%)$ and sideward (10\%) directions. More recently, Bailly et al. (94) also reported the forward direction to be the most common fall 
Table V. Situational event of recreational skiing and snowboarding head injury cases.

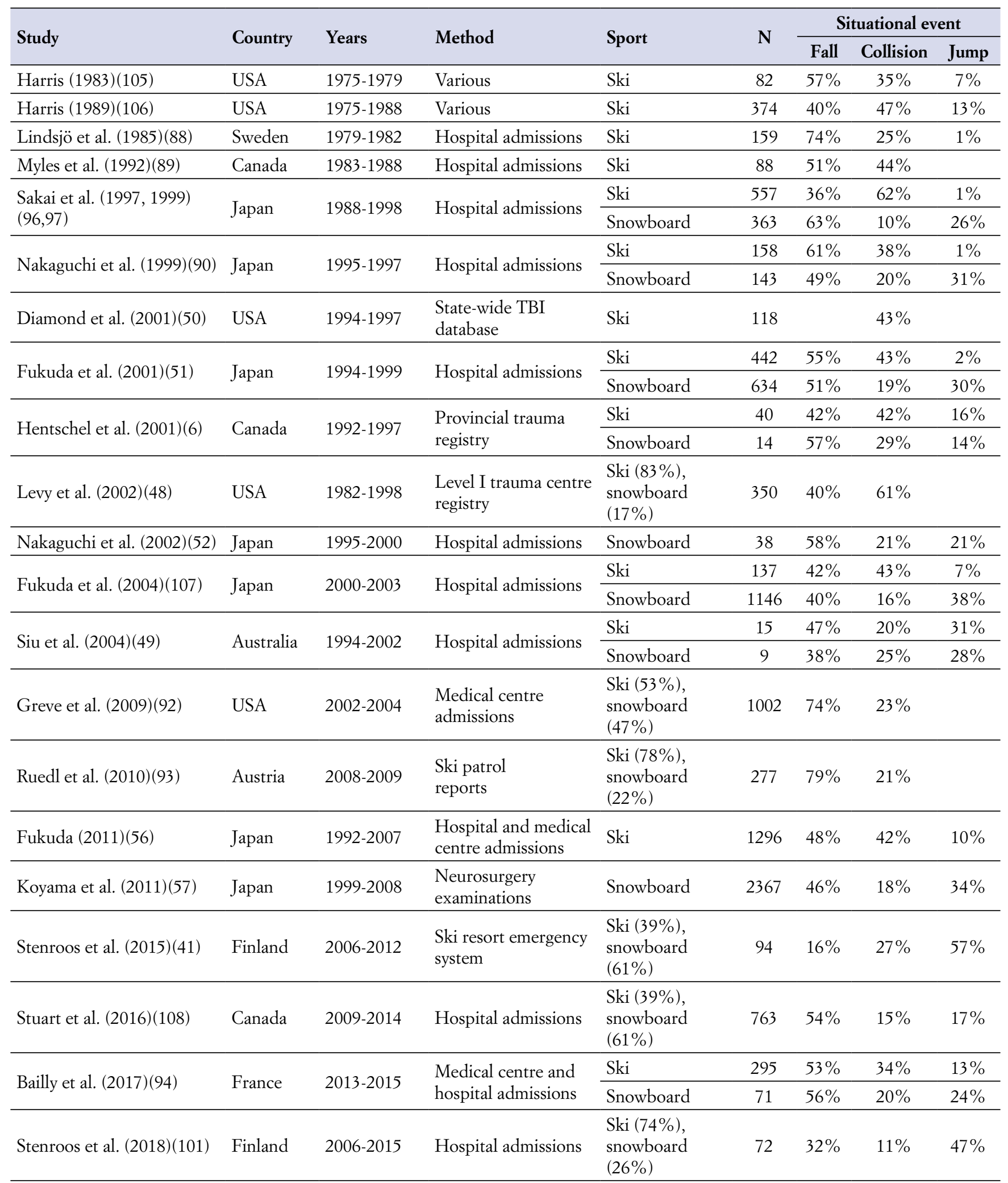


type for skiers (35\%) followed by the sideward (23\%) and rearward $(18 \%)$ directions. In addition, 'crossing skis' and 'spreading skis' were reported as the fall type in $15 \%$ and $5 \%$ of cases, respectively. In contrast, most falls causing head injuries to snowboarders were most commonly in the rearward direction $(48-79 \%)$ followed by the forward $(9-45 \%)$ and sideward (6-12\%) directions $(52,90,94)$. Rearward falls in snowboarding typically occur when the rear edge of the snowboard catches on the snow, which is known as the 'rear edge phenomenon' $(51,52,57,90)$ Sakai et al. (103) reported that fall-related head injuries in snowboarding were due to rear edge catches in two-thirds of cases (66\%). Uzura et al. (112) detailed a case report regarding a subdural haematoma sustained by a snowboarder after impacting the occiput during a rearwards fall after catching an edge on a steep slope.

\section{COLLISIONS}

Reports from older studies are extremely varied for collision-related head injuries in skiing and snowboarding (table VI). More recent studies have reported that collision-related head injuries in skiing are fairly evenly distributed between collisions involving another person $(50-55 \%)$ and collisions with fixed objects $(45-50 \%)(41,94)$. In contrast, collision-related head injuries in snowboarding typically involve another person $(71-100 \%)$ and collisions with fixed objects are less common (0-29\%) (31,33). Stenroos et al. (101) reported $86 \%$ of collisions with fixed objects occurred in an urban setting and the remaining $14 \%$ occurred in terrain parks. In contrast, all collisions involving another person occurred on slopes.

Table VI. Collision types of recreational skiing and snowboarding head injury cases.

\begin{tabular}{|c|c|c|c|c|c|c|c|c|c|}
\hline \multirow{3}{*}{ Study } & \multirow{3}{*}{ Country } & \multirow{3}{*}{ Years } & \multirow{3}{*}{ Method } & \multirow{3}{*}{ Sport } & \multirow{3}{*}{$\mathbf{N}$} & \multicolumn{4}{|c|}{ Collision } \\
\hline & & & & & & \multicolumn{2}{|c|}{ Person } & \multicolumn{2}{|c|}{ Object } \\
\hline & & & & & & Skier & $\begin{array}{l}\text { Snow- } \\
\text { boarder }\end{array}$ & Tree & Other \\
\hline $\begin{array}{l}\text { Oh et al. } \\
(1979)(86)\end{array}$ & Switzerland & $\begin{array}{l}1974- \\
1979\end{array}$ & $\begin{array}{l}\text { Neurosurgery } \\
\text { examinations }\end{array}$ & Ski & 32 & $24 \%$ & & \multicolumn{2}{|c|}{$76 \%$} \\
\hline $\begin{array}{l}\text { Lang et al. (1980) } \\
(113)\end{array}$ & Austria & $\begin{array}{l}1976- \\
1978 \\
\end{array}$ & $\begin{array}{l}\text { Medical centre } \\
\text { admissions }\end{array}$ & Ski & 243 & $69 \%$ & & $8 \%$ & $19 \%$ \\
\hline $\begin{array}{l}\text { Lindsjö et al. } \\
(1985)(88)\end{array}$ & Sweden & $\begin{array}{l}1979- \\
1982\end{array}$ & Hospital admissions & Ski & 159 & $50 \%$ & & $35 \%$ & $15 \%$ \\
\hline $\begin{array}{l}\text { Lystad (1989) } \\
(114)\end{array}$ & Norway & $\begin{array}{l}1982- \\
1986\end{array}$ & $\begin{array}{l}\text { Medical centre } \\
\text { admissions }\end{array}$ & Ski & 158 & $28 \%$ & & $26 \%$ & $46 \%$ \\
\hline $\begin{array}{l}\text { Myles et al. (1992) } \\
(89)\end{array}$ & Canada & $\begin{array}{l}1983- \\
1988 \\
\end{array}$ & Hospital admissions & Ski & 88 & $16 \%$ & & $49 \%$ & $35 \%$ \\
\hline \multirow{2}{*}{$\begin{array}{l}\text { Hentschel et al. } \\
(2001)(6)\end{array}$} & \multirow[t]{2}{*}{ Canada } & \multirow{2}{*}{$\begin{array}{l}1992- \\
1997 \\
\end{array}$} & \multirow{2}{*}{$\begin{array}{l}\text { Provincial trauma } \\
\text { registry }\end{array}$} & Ski & 40 & $13 \%$ & & $81 \%$ & $6 \%$ \\
\hline & & & & Snowboard & 14 & $0 \%$ & & $50 \%$ & $50 \%$ \\
\hline \multirow{2}{*}{$\begin{array}{l}\text { Fukuda et al. } \\
(2004)(107)\end{array}$} & \multirow[t]{2}{*}{ Japan } & \multirow{2}{*}{$\begin{array}{l}2000- \\
2003\end{array}$} & \multirow[t]{2}{*}{ Hospital admissions } & Ski & 137 & $29 \%$ & $63 \%$ & & $8 \%$ \\
\hline & & & & Snowboard & 1146 & $9 \%$ & $82 \%$ & & $9 \%$ \\
\hline $\begin{array}{l}\text { Fukuda (2011) } \\
(56)\end{array}$ & Japan & $\begin{array}{l}1992- \\
2007\end{array}$ & $\begin{array}{l}\text { Hospital and } \\
\text { medical centre } \\
\text { admissions }\end{array}$ & Ski & 1296 & $50 \%$ & $42 \%$ & & $8 \%$ \\
\hline \multirow{2}{*}{$\begin{array}{l}\text { Stenroos et al. } \\
(2015)(41)\end{array}$} & \multirow[t]{2}{*}{ Finland } & \multirow{2}{*}{$\begin{array}{l}2006- \\
2012\end{array}$} & \multirow{2}{*}{$\begin{array}{l}\text { Ski resort emergency } \\
\text { system }\end{array}$} & Ski & 37 & $50 \%$ & & & $50 \%$ \\
\hline & & & & Snowboard & 57 & $100 \%$ & & & $0 \%$ \\
\hline
\end{tabular}




\section{COLLISIONS WITH OBJECTS}

Nachbauer et al. (115) reported that skiers determined responsible for collisions and victims of collisions sustained head injuries in $54 \%$ and $39 \%$ of skier-to-skier collisions, respectively. In a subsequent study, Burtscher et al. (116) reported that approximately $38 \%$ of all skiers involved in a collision sustained a head injury. For ski collisions involving trees, Frermood et al. (117) found a significantly greater proportion of intracranial head injuries and/or skull fractures compared to skiers that did not collide with a tree. More recently, Bailly et al. (94) found that almost half of serious head injuries (48\%), with Glasgow Coma Scores of less than 13, involved collisions with objects. In addition, head injuries from collisions with objects were found to occur on novice or intermediate slopes $(62 \%)$. Stenroos et al. (101) reported that only $14 \%$ of collisions with fixed objects that resulted in head injury occurred in terrain parks and the remaining $86 \%$ occurred in urban environments, which involves skiers and snowboarders sliding on handrails and jumping off structures.

\section{COLLISIONS WITH PERSONS}

In an early study, Oh et al. (118) investigated head injuries sustained from skier-to-skier collisions and found that typically one skier was impacted to the side and sustained a severe head injury, whereas the other skier was impacted to the front and sustained only a minor, or no, head injury. Nachbauer et al. (115) reported that $54 \%$ and $39 \%$ of collision victims and skiers responsible for collisions sustained head injuries, respectively. In contrast, Burtscher et al. (116) reported that $30 \%$ of collision victims and $46 \%$ of skiers

Table VII. Recreational skiing and snowboarding head injuries sustained in terrain parks.

\begin{tabular}{|c|c|c|c|c|c|c|c|c|c|c|}
\hline \multirow[b]{2}{*}{ Study } & \multirow[b]{2}{*}{ Country } & \multirow[b]{2}{*}{ Years } & \multirow[b]{2}{*}{ Method } & \multirow[b]{2}{*}{ Sport } & \multirow[b]{2}{*}{ Injury } & \multirow[b]{2}{*}{$\mathbf{N}$} & \multicolumn{2}{|c|}{ Percentage of all injuries } & \multicolumn{2}{|c|}{ Ratio effect estimate } \\
\hline & & & & & & & TP & Non-TP & $\begin{array}{c}\text { Value } \\
(95 \% \mathrm{CI}) \\
\end{array}$ & Analysis \\
\hline \multirow{2}{*}{$\begin{array}{l}\text { Goulet et } \\
\text { al. (2007) } \\
\text { (99) }\end{array}$} & \multirow{2}{*}{ Canada } & \multirow{2}{*}{$\begin{array}{l}2001- \\
2005\end{array}$} & \multirow{2}{*}{$\begin{array}{l}\text { Ski patrol } \\
\text { reports }\end{array}$} & Ski & $\begin{array}{l}\text { Head/neck } \\
\text { (severe) }\end{array}$ & 2077 & $11 \%$ & $7 \%$ & $\begin{array}{c}1.21 \\
(1.01-1.45) \\
\end{array}$ & \multirow{2}{*}{$\begin{array}{l}\text { Adjusted } \\
\text { OR }\end{array}$} \\
\hline & & & & Snowboard & $\begin{array}{l}\text { Head/neck } \\
\text { (severe) }\end{array}$ & 2864 & $12 \%$ & $11 \%$ & $\begin{array}{c}0.95 \\
(0.84-1.08)\end{array}$ & \\
\hline \multirow{3}{*}{$\begin{array}{l}\text { Moffat et } \\
\text { al. (2009) } \\
(100)\end{array}$} & \multirow{3}{*}{ USA } & \multirow{3}{*}{$\begin{array}{l}2006- \\
2007\end{array}$} & \multirow{3}{*}{$\begin{array}{l}\text { Level I } \\
\text { trauma } \\
\text { centre } \\
\text { registry }\end{array}$} & \multirow{3}{*}{$\begin{array}{l}\text { Ski, } \\
\text { snowboard }\end{array}$} & Head/neck & 94 & $33 \%$ & $27 \%$ & & \\
\hline & & & & & $\begin{array}{l}\text { Closed head } \\
\text { injury }\end{array}$ & 35 & $14 \%$ & $10 \%$ & & \\
\hline & & & & & $\begin{array}{l}\text { Skull/facial } \\
\text { fracture }\end{array}$ & 15 & $4 \%$ & $5 \%$ & & \\
\hline \multirow{4}{*}{$\begin{array}{l}\text { Brooks et } \\
\text { al. (2010) } \\
(34)\end{array}$} & \multirow{4}{*}{ USA } & \multirow{4}{*}{$\begin{array}{l}2000- \\
2005\end{array}$} & \multirow{4}{*}{$\begin{array}{l}\text { Ski patrol } \\
\text { reports }\end{array}$} & \multirow{2}{*}{ Ski } & Head & 443 & $17 \%$ & $7 \%$ & $\begin{array}{c}1.70 \\
(1.32-2.18) \\
\end{array}$ & \multirow{4}{*}{$\begin{array}{c}\text { Multi- } \\
\text { variable } \\
\text { RR }\end{array}$} \\
\hline & & & & & Concussion & 341 & $16 \%$ & $5 \%$ & $\begin{array}{c}2.13 \\
(1.61-2.82)\end{array}$ & \\
\hline & & & & \multirow{2}{*}{ Snowboard } & Head & 1133 & $15 \%$ & $10 \%$ & $\begin{array}{c}1.26 \\
(1.10-1.45) \\
\end{array}$ & \\
\hline & & & & & Concussion & 947 & $15 \%$ & $8 \%$ & $\begin{array}{c}1.59 \\
(1.36-1.85)\end{array}$ & \\
\hline
\end{tabular}

Goulet et al. (99) defined severe injury as per Lipskie (16). TP: terrain park. CI: confidence interval. OR: odds ratio. RR: Risk ratio. 
responsible for collisions sustained head injuries. More recent studies have identified that collisions with other skiers and snowboarders comprise $10-25 \%$ of all head injury cases $(94,119)$. Bailly et al. (94) also identified that collisions with other skiers and snowboarders particularly affected youth, females and lower-skilled skiers and snowboarders. In $62 \%$ of collision-related head injury cases involving other skiers and snowboarders, Bailly et al. (94) found that the 'impacting' skier or snowboarder was moving at high speed while the 'impacted' skier or snowboarder was stationary or moving at low speed (94). Not surprisingly, Stenroos et al. (101) reported all collisions involving another person occurred on slopes.

\section{JUMPS}

The first known terrain park was built in 1986 at Snow Summit, CA and the first known terrain park open to the public was built in 1991 at Bear Mountain, CA (120). Terrain parks are specific areas of alpine sport resorts, which contain features such as jumps that allow skiers and snowboarders to perform maneuvers and tricks. Prior to the introduction of terrain parks, jumping was actively discouraged within resorts. Therefore, skiers and snowboarders built jumps outside alpine sport resorts or secretly inside the boundaries (121). Over the last three decades, the proportion of alpine sport resorts with terrain parks has steadily increased to $94 \%$ as of 2010 (122). It is not uncommon for major alpine sport resorts to have multiple terrain parks of varying difficulty (123).

From 1996 to 2001, Fukuda (124) identified a linear increase in the proportion of snowboarding head injuries from jumps: $23 \%$ to $33 \%\left(\mathrm{R}^{2}=0.98\right)$. In contrast, Shealy et al. (10) found no increase in the prevalence or incidence of injury from jumping from 2000 to 2010 despite an increase in terrain parks. The proportion of head injuries has been found to be greater in terrain parks for skiers and snowboarders (table VII). Henrie et al. (125) reported the proportion of head and spine injuries sustained in terrain parks was approximately twice double the proportion sustained on general slopes. Interestingly, Bailly et al. (94) found that just over half of all head injuries from jumps were sustained in terrain parks $(55 \%)$, whereas the remainder were sustained on novice and intermediate slopes $(31 \%)$ and off-pise $(14 \%)$. As expected, most jump-related head injuries that involved forward and rearward crashes impacted the facial/frontal $(74 \%)$ and occipital $(72 \%)$ regions of the head, respectively (94) Uzura et al. (112) detailed a case report regarding a subdural haematoma sustained by a snowboarder impacting the right temporal region after jumping and falling sideward. Stenroos et al. (101) reported $76 \%$ of jump-related head injuries occurred in terrain parks, whereas $21 \%$ and $3 \%$ occurred in urban environments and on the slopes, respectively.

Terrain parks do not just contain aerial features, but non-aerial features such as boxes, rails and quarter-pipes. Carús et al. $(126,127)$ found that the proportion of head injuries sustained on aerial features of terrain parks by skiers (14\%) was higher than for non-aerial features $(9 \%)$. Similarly, Russel et al. (128) found that the proportion of head injuries sustained on aerial features of terrain parks by snowboarders $(15 \%)$ was higher than for non-aerial features $(9 \%)$. More specifically, Russel (129) found that the most common feature on which snowboarders sustained head injuries were jumps $(38 \%)$ followed by kickers $(29 \%)$, boxes $(10 \%)$, quarter-pipes $(8 \%)$ and half-pipes $(6 \%)$. Interestingly, Russel (129) reported four cases of concussion, which were sustained by snowboarders in the terrain park, but not on any specific features, i.e. snowboarding between features.

\section{HEAD IMPACT SITE}

Few studies have reported the incident location of recreational skiing and snowboarding head injury cases (table VIII). For skiing, head impacts causing injury are primarily to frontal $(37-56 \%)$ and occipital $(33-41 \%)$ regions. For snowboarding head injury cases, the occiput is the most common impact region $(53-68 \%)$ followed by the frontal region $(16-37 \%)$. Relatively few impacts to the temporal $(3-18 \%)$ and parietal $(1-7 \%)$ regions cause head injury in skiing and snowboarding.

\section{HEAD IMPACT BIOMECHANICS}

\section{Kinematics}

To investigate the biomechanics of head impacts in skiing and snowboarding, kinematic boundary conditions are required to be identified, such as the horizontal speed of the skier or snowboarder in the plane of the slope. No studies have reported impact speeds in skiing and snowboarding speeds in regard to head injury crashes, but several studies have reported the general speeds of recreational skiers and snowboarders at resorts (table IX). For skiers of all ages and skill levels on all slope difficulty levels, the mean speed was $12.4 \mathrm{~m} / \mathrm{s}$ with a maximum of $30.1 \mathrm{~m} / \mathrm{s}$. For snowboarders of all ages and skill levels on all slope difficulty levels, the mean speed was 11.1 $\mathrm{m} / \mathrm{s}$ with a maximum of $22.0 \mathrm{~m} / \mathrm{s}$. Skiers tend to travel faster than snowboarders. In addition, skiers and snowboarders of higher skill levels tend to travel faster compared to lower skill levels. Dickson et al. $(130,131)$ reported that youth skiers and snowboarders travelled at mean speeds of 12.2 and 11.1 $\mathrm{m} / \mathrm{s}$, respectively, which are similar to the mean speeds for 
Table VIII. Head impact site for recreational skiing and snowboarding head injury cases.

\begin{tabular}{|c|c|c|c|c|c|c|c|c|c|}
\hline \multirow{2}{*}{ Study } & \multirow{2}{*}{ Country } & \multirow{2}{*}{ Years } & \multirow{2}{*}{ Method } & \multirow{2}{*}{ Sport } & \multirow{2}{*}{$\mathbf{N}$} & \multicolumn{4}{|c|}{ Sites } \\
\hline & & & & & & Frontal & Temporal & Parietal & Occipital \\
\hline $\begin{array}{l}\text { Nakaguchi et al. (1999) } \\
(90)\end{array}$ & Japan & $1995-1997$ & $\begin{array}{l}\text { Hospital } \\
\text { admissions }\end{array}$ & Ski & 158 & $56 \%$ & $3 \%$ & $7 \%$ & $33 \%$ \\
\hline \multirow[t]{2}{*}{ Fukuda et al. (2001)(51) } & \multirow[t]{2}{*}{ Japan } & \multirow[t]{2}{*}{ 1994-1999 } & \multirow{2}{*}{$\begin{array}{l}\text { Hospital } \\
\text { admissions }\end{array}$} & Ski & 442 & $37 \%$ & $18 \%$ & $4 \%$ & $41 \%$ \\
\hline & & & & Snowboard & 634 & $24 \%$ & $12 \%$ & $1 \%$ & $63 \%$ \\
\hline $\begin{array}{l}\text { Koyama et al. (2011) } \\
(57)\end{array}$ & Japan & $1999-2008$ & $\begin{array}{l}\text { Neurosurgery } \\
\text { examinations }\end{array}$ & Snowboard & 2367 & $24 \%$ & $10 \%$ & $4 \%$ & $62 \%$ \\
\hline
\end{tabular}

Table IX. Speeds of recreational skiers and snowboarders.

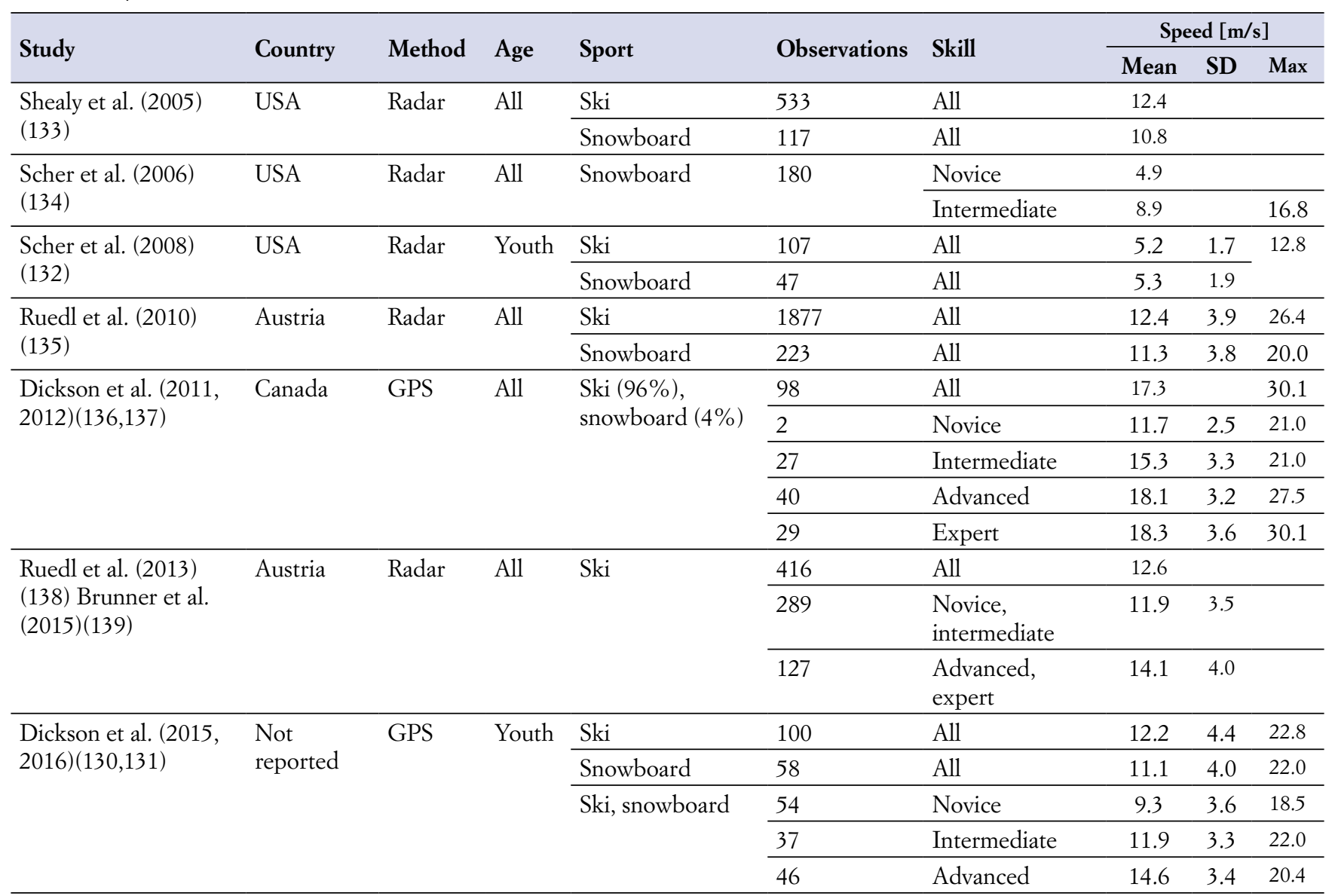

all skiers and snowboarders. An earlier study by Scher et al. (132) reported much slower speeds for youth skiers and snowboarders: 5.2 and $5.3 \mathrm{~m} / \mathrm{s}$, respectively.

Greenwald et al. (140) instrumented the helmets of 46 youth snowboarders with the Head Impact Telemetry
(HIT) System and 674 sensor events were recorded at a snow resort in the United States during the winter of 20072008. More sensor events were recording in the terrain park compared to regular slopes. The highest peak linear and angular head accelerations were $113 \mathrm{~g}$ and $9515 \mathrm{rad} / \mathrm{s}^{2}$; 
respectively, whereas $95 \%$ of impacts had a peak linear head acceleration of less than $50 \mathrm{~g}$. No concussions were medically diagnosed. A similar study on 107 school skiers and snowboarders at Australian snow resorts during the winters of 2009 to 2011 was conducted by Dickson et al. $(131,141,142)$ The HIT System was coupled with global positioning system (GPS) data to remove false-positives, after which only three impacts head peak linear accelerations greater than $40 \mathrm{~g}$.

\section{FALLS}

If a skier or snowboarder falls while stationary, the impact can be idealised as a simple fall from standing height. Head impacts with a purely translational component are often experimentally replicated using a drop test as part of helmet standards (table $\mathbf{X}$ ). A drop test rig comprises a drop tower and carriage with a head form attached. A trixial accelerometer is mounted inside the head form to record the acceleration at the centre of gravity. The helmet is attached to the head form and the carriage is raised to a height that correlates with the desired impact speed. For drops onto a flat anvil, impact speeds range from 4.5 to $6.8 \mathrm{~m} / \mathrm{s}$, which correlate to drop heights of 1.03 to $2.36 \mathrm{~m}$. The Snell standards stipulate impact severity in terms of energy $(143,144)$. For an example drop carriage mass of $5 \mathrm{~kg}$, an impact energy of $120 \mathrm{~J}$ onto a flat anvil correlates to a drop height of $2.45 \mathrm{~m}$ and impact speed of $6.93 \mathrm{~m} / \mathrm{s}$. Some standards also require impacts onto hazard anvils, such as hemispherical or edge anvils. Linear head acceleration limits range from 250 to $300 \mathrm{~g}$, which are in the range associated with skull fracture (145-147).

Dickson et al. $(9,130,131,142)$ has repeatedly stated that the speeds of skiers far exceed the impact speeds used in helmet standards and suggested that the impact speed of the standard be increased. In collisions with fixed objects, travel speed is critical. For falls, the travelling speed of a skier or snowboarder is tangential to the slope and does no contribute to the normal component of a fall onto the slope surface, which can be estimated from standing height. As the speed of a skier or snowboarder increases, the impact vector becomes more oblique, whereas the normal component remains unchanged. Similarly, motorcycles in Australia can legally travel up to $110 \mathrm{~km} / \mathrm{h}(30.6 \mathrm{~m} / \mathrm{s})$ on some major roads, but the Australian Standard for motorcycle helmets requires a drop test from $2.5 \mathrm{~m}$, which is equivalent to an impact speed of $7.0 \mathrm{~m} / \mathrm{s}$. (152) No alpine sport helmet requires an oblique impact test.

To investigate correlation between helmet impacts onto rigid anvils and snow surfaces, studies have performed helmet impacts onto snow surfaces. Dressler et al. ${ }^{153}$ investigated the protective potential of a ski helmet, which was certified to the ASTM standard (148). Drop tests at $4 \mathrm{~m} / \mathrm{s}$ were performed onto soft and hard snow samples with the latter being frozen overnight. For soft snow impacts, no significant differences were found between the helmeted and non-helmeted conditions and all peak linear head

Table X. Standards for Ski and Snowboarding Helmets.

\begin{tabular}{|c|c|c|c|c|c|c|}
\hline \multirow{2}{*}{ Source } & \multirow{2}{*}{ Standard } & \multirow{2}{*}{ Title } & \multirow{2}{*}{ Year } & \multicolumn{3}{|c|}{ Impact attenuation } \\
\hline & & & & Anvil & Severity & Limit $[g]$ \\
\hline \multirow{3}{*}{$\begin{array}{l}\text { American Society for } \\
\text { Testing and Materials }\end{array}$} & \multirow{3}{*}{$\begin{array}{l}\text { ASTM F2040 } \\
(148)\end{array}$} & \multirow[t]{3}{*}{ Recreational snow sports } & \multirow[t]{3}{*}{2018} & Flat & $6.20 \mathrm{~m} / \mathrm{s}$ & \multirow[t]{3}{*}{300} \\
\hline & & & & Hemispherical (Ø $96 \mathrm{~mm})$ & $4.80 \mathrm{~m} / \mathrm{s}$ & \\
\hline & & & & Edge & $4.50 \mathrm{~m} / \mathrm{s}$ & \\
\hline \multirow{2}{*}{$\begin{array}{l}\text { Canadian Standards } \\
\text { Association }\end{array}$} & \multirow{2}{*}{$\begin{array}{l}\text { CSA Z263.1 } \\
(149)\end{array}$} & \multirow{2}{*}{$\begin{array}{l}\text { Recreational alpine skiing } \\
\text { and snowboarding helmets }\end{array}$} & \multirow[t]{2}{*}{2014} & \multirow[t]{2}{*}{ Flat } & $4.50 \mathrm{~m} / \mathrm{s}$ & 250 \\
\hline & & & & & $5.40 \mathrm{~m} / \mathrm{s}$ & 250 \\
\hline $\begin{array}{l}\text { European Committee } \\
\text { for Standardization }\end{array}$ & EN 1077 (150) & $\begin{array}{l}\text { Helmets for alpine skiers } \\
\text { and snowboarders }\end{array}$ & 2007 & Flat & $5.42 \mathrm{~m} / \mathrm{s}$ & 250 \\
\hline $\begin{array}{l}\text { Fédération } \\
\text { Internationale de Ski* }\end{array}$ & FIS (151) & Crash Helmets & 2018 & Flat & $6.80 \mathrm{~m} / \mathrm{s}$ & 250 \\
\hline \multirow{6}{*}{$\begin{array}{l}\text { Snell Memorial } \\
\text { Foundation }\end{array}$} & \multirow{3}{*}{$\begin{array}{l}\text { Snell RS-98 } \\
(143)\end{array}$} & \multirow{3}{*}{$\begin{array}{l}\text { Recreational skiing and } \\
\text { snowboarding }\end{array}$} & \multirow[t]{3}{*}{1998} & Flat & $100 \mathrm{~J}$ & \multirow[t]{3}{*}{300} \\
\hline & & & & Hemispherical (Ø $96 \mathrm{~mm})$ & $80 \mathrm{~J}$ & \\
\hline & & & & Edge & & \\
\hline & \multirow{3}{*}{$\begin{array}{l}\text { Snell S-98 } \\
(144)\end{array}$} & \multirow{3}{*}{$\begin{array}{l}\text { Skiing and other winter } \\
\text { activities }\end{array}$} & \multirow[t]{3}{*}{1998} & Flat & $120 \mathrm{~J}$ & \multirow[t]{3}{*}{300} \\
\hline & & & & Hemispherical (Ø $96 \mathrm{~mm})$ & $100 \mathrm{~J}$ & \\
\hline & & & & Edge & & \\
\hline
\end{tabular}

*FIS certified helmets must also meet ASTM F2040 and EN 1077. 
form accelerations remained below $42 \mathrm{~g}$. In contrast, hard snow impacts to the crown of the non-helmeted and helmeted head form resulted in peak linear acceleration ranges of 138-165 g and 79-98 g, respectively; therefore, the presence of the ski helmet was found to significantly reduce peak linear head form accelerations by $32-48 \%$. The quality and consistency of snow samples was a limitation and it was suggested that future studies investigate snow hardness at ski resorts.

Numerical models have also been used to investigate head impacts onto snow. Kleiven et al. $(154,155)$ evaluated the performance requirements for the European downhill and super-g ski helmet standard (150). A helmeted Hybrid III head form was dropped onto ski slopes, the acceleration and high-speed video data from which were used to reconstruct the oblique impacts and validate a finite element snow model. In addition, video footage of alpine skiing crashes were collected and analysed to obtain head impact kinematics, ${ }^{4,155}$ which indicate that substantial rotational forces are experienced by the head during impacts. One limitation was that the head form was released by hand; therefore, issues with pre-impact rotations were experienced. More recently, Bailly et al. (156) obtained the damping properties of hard and soft snow by performing drop tests on ski slopes using a rigid head form to develop a numerical model. Mean peak linear accelerations for 1.5, 2.0 and $3.0 \mathrm{~m}$ simulated drop tests ranged from 72 to $138 \mathrm{~g}$ for hard snow and 42 to $81 \mathrm{~g}$ for soft snow, respectively.

Simple falls from standing height have been investigated using anthropomorphic test devices (ATDs) (157-159). Similarly, ATDs have been used to simulate rearward falls onto snow slopes resulting in occipital head impact $(134,160,161)$, which has been identified as the situational event of over half of all major head injuries to snowboarders $(51,52,57,90)$. An Hybrid III ATD was accelerated along a cable and released at approximately $8 \mathrm{~m} / \mathrm{s}$ onto a snow-covered ramp with a gradient of $20^{\circ}$, which was used to replicate a snow slope. For soft snow impacts to the occiput, no significant protective effect was observed in the helmeted tests and all peak linear head form accelerations remained below $83 \mathrm{~g}$ for all soft snow impacts and no significant differences were found between the helmeted and non-helmeted conditions. In contrast, icy snow impacts to the occiput of the non-helmeted and helmeted head form resulted in mean peak linear accelerations of $391 \mathrm{~g}$ and $162 \mathrm{~g}$, respectively; therefore, the presence of the ski helmet was found to significantly reduce peak linear head form accelerations by a factor of over two. The need to correlate helmet test standards to real-world impacts was identified (161).

Bailly et al. (156) simulated rearward falls of non-helmeted snowboarders, which were previously reconstructed using an ATD $(134,160,161)$. The peak linear head form accelerations were found to be similar for soft snow impacts; however, the numerical simulations underestimated the peak linear acceleration of the ATD head form for the hard snow impacts. A parametric study of rearward snowboarding falls identified that the size of the snowboarder, initial velocity and snow stiffness influenced head injury risks. It was concluded that a relevant impacting surface and more demanding acceleration criteria should be considered for inclusion in performance standards for ski and snowboard helmets.

Although it is possible to alter the magnitude of head form linear acceleration, by altering the drop height, equivalent to an impact onto a snow surface, the duration of the rigid anvil impact will be shorter than the snow surface impact. Once snow surfaces of varying hardness are characteristed, suitable anvils with similar material properties may be used instead of rigid anvils to achieve a similar head form linear acceleration pulse in terms of magnitude and duration. In addition, situation event data could be used to provide sport-specific helmet performance standards, i.e. different standards for ski and snowboarding helmets. For example, a ski helmet standard may include a more severe oblique test to the front of the helmet, whereas a snowboard helmet standard may include a drop test onto the occipital region.

\section{COLLISIONS}

In addition to falls, ATDs have also been used to investigate collisions in skiing and snowboarding. Scher et al. (132) used ATDs in a pendulum configuration to replicate skier-to-pole and skier-to-skier frontal impacts. The presence of a helmet was associated with a significant decrease in peak linear head form accelerations for both skier-to-pole and skier-to-skier impacts. Decreases in peak angular head form accelerations were observed for both impact configurations; however, only the results from the skier-to-skier configuration were significant. Muser et al. (162) used ATDs equipped with skis, poles, skiing attire and helmets to reconstruct a $90^{\circ}$ impact between two skiers. One skier was stationary and oriented at $90^{\circ}$ to the other skier travelling at 8.3 and $13.9 \mathrm{~m} / \mathrm{s}$. For the $8.3 \mathrm{~m} / \mathrm{s}$ impact, the mean peak linear head acceleration for both ATDs was $103 \mathrm{~g}$, which is comparable to the mean peak head accelerations experienced by Australian football players during a concussion impact (163). Surprisingly, mean peak head acceleration for the $13.9 \mathrm{~m} / \mathrm{s}$ impact was $91 \mathrm{~g}$. However, Muser et al. (162) reported that the head and torso made initial contact for the 8.3 and $13.9 \mathrm{~m} / \mathrm{s}$ impacts, respectively. Petrone et al. (164) developed an ATD, which was constructed using an ANSI head form and a Hybrid II neck form, to investigate high 
speed helmeted collisions into safety nets and foam mats (165). Speeds of up to $18.3 \mathrm{~m} / \mathrm{s}$ were achieved with an $18 \mathrm{~m}$ pendulum rig, which resulted in peak head form accelerations of up to $189 \mathrm{~g}$.

Physical reconstructions of collisions have demonstrated that peak linear acceleration of the head form varies depending on the impact object. Similar to impact testing of American football helmets (166), a performance standard test for alpine helmets could incorporate common impacting surfaces, such as poles and other skiers, using a linear impactor. Rotation of a head form during a linear impact test allows for the measurement of rotational kinematics, which have long been associated with diffuse head injuries (167-169).

\section{JUMPS}

After instrumenting a snowboarding during jumps, Shealy et al. (170) reported mean resultant linear accelerations of $74.6 \mathrm{~g}, 3.7 \mathrm{~g}$ and $2.5 \mathrm{~g}$ at the boot, chest and head, respectively. It was concluded that when the snowboarder lands correctly, the lower limb structure significantly attenuated the impact acceleration. Such a finding supports the results of an early study of human tolerance to vertical impact, in which accelerations of up to $250 \mathrm{~g}$ could be absorbed when subjects landed with legs flexed with only slight pain in the lower limbs (171).

Equivalent fall height (EFH), which is the component of point mass velocity normal to the snow surface in terms of distance, has previously been used to assess the landing height of Nordic ski jumpers (172). Although a safe EFH for terrain park jumps has yet to be established, Hubbard et al. (173) reasoned that $1.0 \mathrm{~m}$ seemed appropriate and found that jumps can be designed with a EFH of $1.0 \mathrm{~m}$ that suit most available sites. EFH is dependent on takeoff speed and angle; however, both variables can be affected by 'pop', which occurs when a skier or snowboarder manipulates take-off by jumping or dropping (174). Another consideration is the design of the launch ramp, which should end with a straight section as a concave launch ramp may cause undesirable rotations and involuntary inversion $(175,176)$. Scher et al. (121) investigated the injury potential of a snowboarder landing inverted using an ATD, which was lifted above a snow surface. For each drop, the ATD was released and made contact with a horizontal bar, which induced rearwards rotation. The snow surface angle and ATD fall distance were altered to provide a range of EFHs from 0.23 to $1.52 \mathrm{~m}$. Peak linear and angular head accelerations of 52-142 $\mathrm{g}$ and $1920-5091 \mathrm{rad} / \mathrm{s}^{2}$, respectively, were recorded across trials and are associated with concussion (163), but below acceleration levels associated with more severe injuries such as subdural haematoma (177) or diffuse axonal injury (178). Therefore, Scher et al. (121) concluded that the risk of severe brain injury was low for impacts from the range of EFH tested.

\section{SUMMARY}

Head injuries in skiing and snowboarding comprise up to $38 \%$ of all injuries, with concussion comprising a substantial portion of all head injuries. Although head injury is responsible for approximately half of all traumatic fatalities occurring on the slopes, fatal injuries are rare with less than $1 \%$ of all skiing head injuries ending in death.

Head injuries typically occur to males aged 23 to 29 years with novice or intermediate level alpine sport skills on mild to moderate slopes. Skiers typically fall forwards impacting the frontal region of the head, whereas snowboarders typically fall backwards impacting the occipital region of the head. Other common head injury situational events involve colliding with objects or other people when skiing and crashing on jumps in terrain parks when snowboarding. Skiers tend to travel faster than snowboarders at speeds of up to 30 and $22 \mathrm{~m} / \mathrm{s}$, respectively. In addition, skiers and snowboarders of higher skill levels tend to travel faster compared to lower skill levels. Some studies have suggested that the impact speed of alpine sport helmet testing standards be increased; however, the travelling speed of a skier or snowboarder is tangential to the slope. As the speed of a skier or snowboarder increases, the impact vector becomes more oblique; however, the normal component remains unchanged. Alpine sports helmet standards require linear drops onto rigid anvils, but the correlation between helmet impacts onto rigid anvils and snow surfaces is unknown. No alpine sport helmet requires an oblique impact test. The presence of a helmet was associated with a significant decrease in peak linear head form accelerations for both skier-to-pole and skier-to-skier impacts. Significant protective effects have been found for skier-to-pole impacts, skierto-skier impacts and fall impacts to hard snow, but not for soft snow. During landing after completing a jump, the lower limb structure significantly attenuates the impact acceleration. In addition, jump design can affect the execution of a jump and equivalent fall height can be related to head injury risk.

Helmets have long been thought to reduce the risk of head injuries in skiing and snowboarding; however, recent studies have reported inconsistent evidence regarding the protective effect of helmets in alpine sports. Performance standards of helmets used in alpine sports should more closely reflect the boundary conditions of head impacts to skiers and snowboarders associated with injury. For 
example, a ski helmet standard may include a more severe oblique test to the front of the helmet, whereas a snowboard helmet standard may include a drop test onto the occipital region. Administrative controls are also methods of injury risk reduction, which may include skill training, separating novice from advanced skiers and snowboarders and/or policy regarding passing another person on the slopes. Lastly, engineering controls may be more effective than both protective equipment and education in terms of injury risk reduction (179). For alpine sports, engineer-

\section{REFERENCES}

1. Flørenes T, Nordsletten L, Heir S, Bahr R. Recording Injuries Among World Cup Skiers and Snowboarders: A Methodological Study. Scandinavian Journal of Medicine \& Science in Sports. 2011;21(2):196-205.

2. Ehrnthaller C, Kusche H, Gebhard F. Differences in Injury Distribution in Professional and Recreational Snowboarding. Open Access Journal of Sports Medicine. 2015;6:109-119.

3. Steenstrup SE, Bakken A, Bere T, Patton DA, Bahr R. Head Injury Mechanisms in FIS World Cup Alpine and Freestyle Skiers and Snowboarders. British Journal of Sports Medicine. 2017;52(1):61-69.

4. Yamazaki J, Gilgien M, Kleiven S, et al. Analysis of a Severe Head Injury in World Cup Alpine Skiing: A Case Report. Medicine \& Science in Sports \& Exercise. 2015;47(6):11131118.

5. Randjelovic S, Heir S, Nordsletten L, Bere T, Bahr R. Injury Situations in Freestyle Ski Cross (SX): A Video Analysis of 33 Cases. British Journal of Sports Medicine. 2014;48(1):29-35.

6. Hentschel S, Hader W, Boyd M. Head Injuries in Skiers and Snowboarders in British Columbia. Canadian Journal of Neurological Sciences. 2001;28(2):42-46.

7. Hagel BE, Pless IB, Platt RW. Trends in Emergency Department Reported Head and Neck Injuries Among Skiers and Snowboarders. Canadian Journal of Public Health. 2003;94(6):458-462.

8. Corra S, Conci A, Conforti G, Sacco G, De Giorgi F. Skiing and Snowboarding Injuries and Their Impact on the Emergency Care System in South Tyrol: A Restrospective Analysis for the Winter Season 2001-2002. Injury Control and Safety Promotion. 2004;11(4):281-285.

9. Dickson TJ, Trathen S, Terwiel FA, Waddington GS, Adams R. Head Injury Trends and Helmet Use in Skiers and Snowboarders In Western Canada, 2008-2009 to 2012-2013: An Ecological Study. Scandinavian Journal of Medicine \& Science in Sports. 2017;27(2):236-244.

10. Shealy JE, Ettlinger CF, Scher IS, Johnson RJ. 2010/2011 NSAA 10-Year Interval Injury Study. 20th International Symposium on Skiing Trauma and Safety, 2013; 2015; Bariloche, Argentina.

11. Sulheim S, Ekeland A, Holme I, Bahr R. Helmet Use and Risk of Head Injuries in Alpine Skiers and Snowboarders: Changes After an Interval of One Decade. British Journal of Sports Medicine. 2017;51(1):44-50. ing controls include slope design (e.g. gradient, grooming, placement and padding of poles, tree removal) and terrain park design (type, placement and size of features, jump geometry).

\section{CONFLICT OF INTERESTS}

McIntosh provides expert witness services, but declares no conflict of interest regarding this paper, its preparation and expert witness services (180).

12. Shealy JE, Johnson RJ, Ettlinger CF, Scher IS. Role of Helmets in Mitigation of Head Injuries: Epidemiologic Study of Head Injuries to Skiers. 20th International Symposium on Skiing Trauma and Safety, 2013; 2015; Bariloche, Argentina.

13. McCrory PR, Meeuwisse WH, Dvořák J, et al. Consensus Statement on Concussion in Sport: The 5th International Conference on Concussion in Sport Held in Berlin, October 2016. British Journal of Sports Medicine. 2017;51(11):838847.

14. Gil JA, DeFroda SF, Kriz P, Owens BD. Epidemiology of Snow Skiing- Versus Snowboarding-Related Concussions Presenting to the Emergency Department in the United States from 2010 to 2014 [Epub]. Clinical Journal of Sport Medicine. 2017.

15. Bergmann KR, Flood A, Kreykes NS, Kharbanda AB. Concussion Among Youth Skiers and Snowboarders: A Review of the National Trauma Data Bank From 2009 to 2010. Pediatric Emergency Care. 2016;32(1):9-13.

16. Lipskie TL. An Epidemiologic Investigation of Snowboarding Injuries: Rates and Risk Factors [Master Thesis]. Ottawa, ON, Canada, University of Ottawa; 2000.

17. Machold W, Kwasny O, Gässler P, et al. Risk of Injury Through Snowboarding. Journal of Trauma. 2000;48(6):1109-1114.

18. Dohjima T, Sumi Y, Ohno T, Sumi H, Shimizu K. The Dangers of Snowboarding: A 9-Year Prospective Comparison of Snowboarding and Skiing Injuries. Acta Orthopaedica Scandinavica. 2001;72(6):657-660.

19. Drulec JA, Letts M. Snowboarding Injuries in Children. Canadian Journal of Surgery. 2001;44(6):435-439.

20. Federiuk CC, Schlueter JL, Adams AL. Skiing, Snowboarding, and Sledding Injuries in a Northwestern State. Wilderness \& Environmental Medicine. 2002;13(4):245-249.

21. Langran M, Selvaraj S. Increased Injury Risk Among FirstDay Skiers, Snowboarders, and Skiboarders. American Journal of Sports Medicine. 2002a;32(1):96-103.

22. Langran M, Selvaraj S. Snow Sports Injuries in Scotland: A Case-Control Study. British Journal of Sports Medicine. 2002b;36(2):135-140.

23. Bridges EJ, Rouah F, Johnston KM. Snowblading Injuries in Eastern Canada. British Journal of Sports Medicine. 2003;37(6):511-515.

24. Pogorzelski A, McCrory P. Alpine Sports Injuries in Victoria [Abstract]. Journal of Science and Medicine in Sport. 2003;6(4, Supplement 1):52. 
25. Skokan EG, Junkins EP, Jnr, Kadish H. Serious Winter Sport Injuries in Children and Adolescents Requiring Hospitalization. American Journal of Emergency Medicine. 2003;21(2):95-99.

26. Yamagami T, Ishihara H, Kimura T. Clinical Features of Snowboarding Injuries. Journal of Orthopaedic Science. 2004;9(3):225-229.

27. Xiang H, Kelleher K, Shields BJ, Brown KJ, Smith GA. Skiing- and Snowboarding-Related Injuries Treated in U.S. Emergency Departments, 2002. Journal of Trauma. 2005;58(1):112-118.

28. Emery CA, Meeuwisse WH, McAllister JR. Survey of Sport Participation and Sport Injury in Calgary and Area High Schools. Clincal Journal of Sports Medicine. 2006;16(1):2026.

29. Ekeland A, Rødven A. Injuries in Norwegian Ski Resorts the Winter Seasons of 2005 and 2006. Journal of ASTM International. 2008a;5(6):JAI101453.

30. Ekeland A, Rødven A. Injury Trends in Norwegian Ski Resorts in the 10 Year Period 1996-2006. Journal of ASTM International. 2008b;5(6):JAI101620.

31. Hayes JR, Groner JI. The Increasing Incidence of Snowboard-Related Trauma. Journal of Pediatric Surgery. 2008;43(5):928-930.

32. Sakamoto Y, Sakuraba K. Snowboarding and Ski Boarding Injuries in Niigata, Japan. American Journal of Sports Medicine. 2008;36(5):943-948.

33. Wasden CC, McIntosh SE, Keith DS, McCowan C. An Analysis of Skiing and Snowboarding Injuries on Utah Slopes. Journal of Trauma. 2009;67(5):1022-1026.

34. Brooks MA, Evans MD, Rivara FP. Evaluation of Skiing and Snowboarding Injuries Sustained in Terrain Parks Versus Traditional Slopes. Injury Prevention. 2010;16(2):119-122.

35. Ekeland A, Rødven A. Skiing and Boarding Injuries on Norwegian Slopes During Two Winter Seasons. Journal of ASTM International. 2010;7(4):1-8.

36. Ogawa H, Sumi H, Sumi Y, Shimizu K. Skill Level-Specific Differences in Snowboarding-Related Injuries. American Journal of Sports Medicine. 2010;38(3):532-537.

37. Ekeland A, Rødven A. Alpine Skiing, Telemarking, Snowboarding, and Skiboarding Injuries Related to Gender and Ability. Journal of ASTM International. 2012;9(4):JAI104496.

38. Kim S, Endres NK, Johnson RJ, Ettlinger CF, Shealy JE. Snowboarding Injuries: Trends Over Time and Comparisons With Alpine Skiing Injuries. American Journal of Sports Medicine. 2012;40(4):770-776.

39. Russell K, Meeuwisse WH, Nettel-Aguirre A, et al. Comparing the Characteristics of Snowboarders Injured in a Terrain Park who Present to the Ski Patrol, the Emergency Department or Both. International Journal of Injury Control and Safety Promotion. 2014;21(3):244-251.

40. Ehrnthaller C, Kusche H, Gebhard F. Differences in Injury Distribution in Professional and Recreational Snowboarding. Open Access Journal of Sports Medicine. 2015;6(6):109-119.

41. Stenroos AJ, Handolin LE. Incidence of Recreational Alpine Skiing and Snowboarding Injuries: Six Years Experience in the Largest Ski Resort in Finland. Scandinavian Journal of Surgery. 2015;104(2):127-131.

42. Basques BA, Gardner EC, Samuel AM, et al. Injury Patterns and Risk Factors for Orthopaedic Trauma from Snow- boarding and Skiing: A National Perspective [Epub]. Knee Surgery, Sports Traumatology, Arthroscopy. 2016.

43. Weber CD, Horst K, Lefering R, Hofman M, Dienstknecht T, Pape H-C. Major Trauma in Winter Sports: An International Trauma Database Analysis. European Journal of Emergency Medicine. 2016;42(6):741-747.

44. Van Laarhoven SN, Latten G, De Loos E, Van Hemert W, Vles GF. Annual Trauma Load of the World's Largest Indoor Skiing Center. European Journal of Trauma and Emergency Surgery. 2017;43(2):233-237.

45. Summers Z, Teague WJ, Hutson JM, Palmer CS, Jowett HE, King SK. The Spectrum of Pediatric Injuries Sustained in Snow Sports. Journal of Pediatric Surgery. 2017;52(12):20382041.

46. Basques BA, Gardner EC, Samuel AM, et al. Injury Patterns and Risk Factors for Orthopaedic Trauma from Snowboarding and Skiing: A National Perspective. Knee Surgery, Sports Traumatology, Arthroscopy. 2018;26(7):1916-1926.

47. Ekeland A, Rødven A, Heir S. Injuries Among Children and Adults in Alpine Skiing and Snowboarding. Journal of Science and Medicine in Sport. 2019;22(Supplement 1):s3s6.

48. Levy AS, Hawkes AP, Hemminger LM, Knight S. An Analysis of Head Injuries Among Skiers and Snowboarders. Journal of Trauma. 2002;53(4):695-704.

49. Siu TL, Chandran KN, Newcombe RL. Snow Sports Related Head and Spinal Injuries: An Eight-Year Survey from the Neurotrauma Centre for the Snowy Mountains, Australia. Journal of Clinical Neuroscience. 2004;11(3):236-242.

50. Diamond PT, Gale SD, Denkhaus HK. Head Injuries in Skiers: An Analysis of Injury Severity and Outcome. Brain Injury. 2001;15(5):429-434.

51. Fukuda O, Takaba M, Saito T, Endo S. Head Injuries in Snowboarders Compared with Head Injuries in Skiers: Prospective Analysis of 1076 Patients from 1994 to 1999 in Niigata, Japan. American Journal of Sports Medicine. 2001;29(4):437-440.

52. Nakaguchi H, Tsutsumi K. Mechanisms of Snowboarding-Related Severe Head Injury: Shear Strain Induced by the Opposite-Edge Phenomenon. Journal of Neurosurgery. 2002;97(3):542-548.

53. Fukuda O, Hirashima Y, Origasa H, Endo S. Characteristics of Helmet or Knit Cap Use in Head Injury of Snowboarders - Analysis of 1,190 Consecutive Patients. Neurologia Medico-Chirurgica. 2007;47(11):491-494.

54. Fukuda O, Koyama S, Endo S. Head Injuries in Skiers and Snowboarders [Japanese]. Journal of Japanese Society of Clinical Sports Medicine. 2008;16(2):165-171.

55. Simson H, Tator CH. Alpine Skiing. In: Tator CH, ed. Catastrophic Injuries in Sports and Recreation: Causes and Prevention - A Canadian Study. Section 4: Winter Sports. Toronto, ON, Canada: University of Toronto Press; 2008:318-332.

56. Fukuda O. The Serial Characteristic Changes of Skiing Related Head Injury: Analysis of 1,296 Cases in 15 Seasons of 1992/93-2006/07 [Japanese]. Japanese Journal of Clinical Sports Medicine. 2011;19(2):322-327.

57. Koyama S, Fukuda O, Hayashi N, Endo S. Differences in Clinical Characteristics of Head Injuries to Snowboarders by Skill Level. American Journal of Sports Medicine. 2011;39(12):2656-2661. 
58. Rughani AI, Lin C-T, Ares WJ, et al. Helmet Use and Reduction in Skull Fractures in Skiers and Snowboarders Admitted to the Hospital. Journal of Neurosurgery. 2011;7(3):268-271.

59. Corra S, Girardi P, De Giorgi F, Braggion M. Severe and Polytraumatic Injuries Among Recreational Skiers and Snowboarders: Incidence, Demographics and Injury Patterns in South Tyrol. European Journal of Emergency Medicine. 2012;19(2):69-72.

60. Weston J, Moore S, Rich T. A Five-Year Study of Mortality in a Busy Ski Population. Journal of Forensic Sciences. 1977;22(1):222-230.

61. Lange J, Mong W, Hewell T. Fatal and Severe Skiing Accidents. 2nd International Symposium on Skiing Trauma and Safety, 1977; 1978; Granada, Spain.

62. Morrow PL, McQuillen EN, Eaton LA, Jnr, Bernstein CJ. Downhill Ski Fatalities: The Vermont Experience. Journal of Trauma. 1988;28(1):95-100.

63. Sherry E, Clout L. Deaths Associated with Skiing in Australia: A 32 Year Study of Cases from the Snowy Mountains. Medical Journal of Australia. 1988;149(11-12):615-618.

64. Berghold F. Fatal Skiing Accidents in Austria - Epidemiology and Analysis. 7th International Symposium on Skiing Trauma and Safety, 1987; 1989; Keystone, CO, USA.

65. Ruedl G, Bilek H, Ebner H, Gabl K, Kopp M, Burtscher M. Fatalities on Austrian Ski Slopes During a 5-Year Period. Wilderness \& Environmental Medicine. 2011;22(4):326-328.

66. Kunz SN, Keller T, Grove C, Lochner S, Monticelli F. Fatal Skiing Accidents: A Forensic Analysis Taking the Example of Salzburg [German]. Archiv für Kriminologie. 2015;235(12):1-10.

67. Skinner R, Jhirad R, Cass D, et al. Winter Sports Death Review: A Review of All Accidental Skiing, Snowboarding and Tobogganing Deaths in Ontario from January 1, 1991 to December 31, 2012. St Catharines, ON, Canada: Office of the Chief Coroner;2015.

68. Costa-Scorse B, Hume PA. Head Injury Prevention in Alpine Skiing and Snowboarding: Critical Review of Literature and Analysis of Nz Snow Sports Injury Epidemiology. Auckland, New Zealand: Sports Performance Research Institute New Zealand, Auckland University of Technology;2011.

69. Association for the Advancement of Automotive Medicine. Abbreviated Injury Scale: 2015 Revision. Chicago, IL, USA: AAM;2018.

70. Hagel BE, Pless IB, Goulet C, Platt RW, Robitaille Y. Quality of Information on Risk Factors Reported by Ski Patrols. Injury Prevention. 2004;10(5):275-279.

71. Buller DB, Andersen PA, Walkosz BJ, Scott MD, Cutter GR. The Prevalence and Predictors of Helmet Use by Skiers and Snowboarders at Ski Areas in Western North America in 2001. Journal of Trauma. 2003;55(5):939-945.

72. Shealy JE, Johnson RJ, Ettlinger CF. Head Trauma and Helmet Usage in Recreational Skiing [Abstract]. 16th International Society of Skiing Safety Conference, 2005; 2006; Niigata, Japan.

73. Cundy TP, Systermans BJ, Cundy WJ, Cundy PJ, Briggs NE, Robinson JB. Helmets for Snow Sports: Prevalence, Trends, Predictors and Attitudes to Use. Journal of Trauma. 2010;69(6):1486-1490.
74. Ruedl G, Kopp M, Rumpold G, Holzner B, Ledochowski L, Burtscher M. Attitudes Regarding Ski Helmet Use Among Helmet Wearers and Non-Wearers. Injury Prevention. 2012;18(3):182-186.

75. Bailly N, Afquir S, Laporte J-D, et al. Analysis of Injury Mechanisms in Head Injuries in Skiers and Snowboarders. Medicine \& Science in Sports \& Exercise. 2017;49(1):1-10.

76. Lawrence L, Shaha S, Lillis K. Observational Study of Helmet Use Among Children Skiing and Snowboarding. Pediatric Emergency Care. 2008;24(4):219-221.

77. Consumer Product Safety Commission. Skiing Helmets: An Evaluation of the Potential to Reduce Head Injury. Washington, DC, USA: CPSC;1999.

78. Cusimano MD, Kwok J. The Effectiveness of Helmet Wear in Skiers and Snowboarders: A Systematic Review. British Journal of Sports Medicine. 2010;44(11):781-786.

79. Russell K, Christie J, Hagel BE. The Effect of Helmets on the Risk of Head and Neck Injuries Among Skiers and Snowboarders: A Meta-Analysis. Canadian Medical Association Journal. 2010;182(4):333-340.

80. Haider AD, Saleem T, Bilaniuk JW, Barraco RD. An Evidence Based Review: Efficacy of Safety Helmets in Reduction of Head Injuries in Recreational Skiers and Snowboarders. Journal of Trauma and Acute Care Surgery. 2012;73(5):13401347.

81. Baschera D, Hasler RM, Taugwalder D, Exadaktylos AK, Raabe A. Association Between Head Injury and Helmet Use in Alpine Skiers: Cohort Study from a Swiss Level I Trauma Center. Journal of Neurotrauma. 2015;32(8):557-562.

82. Milan M, Jhaij S, Stewart C, Pyle L, Moulton S. Helmet Use and Injury Severity Among Pediatric Skiers and Snowboarders in Colorado. Journal of Pediatric Surgery. 2017;52(2):349-353.

83. Porter ED, Trooboff SW, Haff MG, et al. Helmet Use is Associated with Higher Injury Severity Scores in Alpine Skiers and Snowboarders Evaluated at a Level I Trauma Center. Journal of Trauma and Acute Care Surgery. 2019;87(5):12051213.

84. McIntosh AS, Andersen TE, Bahr R, et al. Sports Helmets Now and in the Future. British Journal of Sports Medicine. 2011;45(16):1258-1265.

85. McIntosh AS. Biomechanical Considerations in the Design of Equipment to Prevent Sports Injury. Journal of Sports Engineering and Technology. 2012;226(3/4):193-199.

86. Oh S-Y. Die Verhütung der Kopfverletzungen beim Skifahren [German]. Schweizerische Zeitschrift für Sportmedizin. 1979;27(4):157-167.

87. Oh S-Y, Schmid UD. Head Injuries in Childhood Caused by Skiing and Their Optimal Prevention [German]. Zeitschrift für Kinderchirurgie. 1983;38(2):66-72.

88. Lindsjö U, Hellquist E, Engkvist O, Balkfors B. Head Injuries in Alpine Skiing. 5th International Symposium on Skiing Trauma and Safety, 1983; 1985b; Keystone, CO, USA.

89. Myles SI, Mohtadi NG, Schnittker J. Injuries to the Nervous System and Spine in Downhill Skiing. Canadian Journal of Surgery. 1992;35(6):643-648.

90. Nakaguchi H, Fujimaki T, Ueki K, Takahashi M, Yoshida $\mathrm{H}$, Kirino T. Snowboard Head Injury: Prospective Study in Chino, Nagano, for Two Seasons from 1995 to 1997. 58th Annual Meeting of the American Association for the Surgery of Trauma; 1999; Baltimore, MD, USA. 
91. Wilkins WC. Emergent Injury Patterns of Snowboarders at Three California Resorts 1999-2000, 2000-2001 [Masters Thesis]. Long Beach, CA, USA: Department of Kinesiology and Physical Education, California State University; 2003.

92. Greve MW, Young DJ, Goss AL, Degutis LC. Skiing and Snowboarding Head Injuries in 2 Areas of the United States. Wilderness \& Environmental Medicine. 2009;20(3):234-238.

93. Ruedl G, Sommersacher R, Woldrich T, Kopp M, Nachbauer W, Burtscher M. Risk Factors of Head Injuries on Austrian Ski Slopes [German]. Deutsche Zeitschrift für Sportmedizin. 2010a;61(4):97-102.

94. Bailly N, Afquir S, Laporte JD, et al. Analysis of Injury Mechanisms in Head Injuries in Skiers and Snowboarders. Medicine \& Science in Sports \& Exercise. 2017;49(1):1-10.

95. Graves JM, Whitehill JM, Stream JO, Vavilala MS, Rivara FP. Emergency Department Reported Head Injuries from Skiing and Snowboarding Among Children and Adolescents, 19962010. Injury Prevention. 2013;19(6):399-404.

96. Sakai H, Murase S, Sumi Y, Takenaka K, Yamakawa H, Sakai N. Snowboarding Head Injuries: Analysis of 109 Cases and Comparison with Skiing Head Injuries [Japanese]. Noshinkeigeka Sokuhou. 1997;7(5):385-390.

97. Sakai H, Yamakawa H, Murase S, Arakawa S, Sumi Y, Sakai N. Mechanism and Prevention of Snowboarding Head Injuries [Japanese]. Journal of Japanese Society of Clinical Sports Medicine. 1999;7:12-16.

98. Ruedl G, Kopp M, Sommersacher R, Woldrich T, Burtscher M. Factors Associated with Injuries Occurred on Slope Intersections and in Snow Parks Compared to On-Slope Injuries. Accident Analysis \& Prevention. 2013;50:1221-1225.

99. Goulet C, Hagel BE, Hamel D, Légaré G. Risk Factors Associated with Serious Ski Patrol-Reported Injuries Sustained by Skiers and Snowboarders in Snow-Parks and on Other Slopes. Canadian Journal of Public Health. 2007;98(5):402-406.

100. Moffat C, McIntosh SE, Bringhurst J, Danenhauer K, Gilmore N, Hopkins CL. Terrain Park Injuries. Western Journal of Emergency Medicine. 2009;10(4):257-262.

101. Stenroos A, Handolin L. Head Injuries in Urban Environment Skiing and Snowboarding: A Retrospective Study on Injury Severity and Injury Mechanisms. Scandinavian Journal of Surgery. 2018;107(2):166-171.

102. German Institute for Standardization. Graphic Symbols and Signs for Information of the Skiers on Skiing Slopes. DIN 32912. Berlin, Germany1983.

103. Sakai H, Murase S, Niikawa S. Snowboarding Head Injuries [Japanese]. Neurotraumatology. 1998;21:94-100.

104. Bahr R, Krosshaug T. Understanding Injury Mechanisms: A Key Component of Preventing Injuries in Sport. British Journal of Sports Medicine. 2003;39(5):324-329.

105. Harris JB. Neurological Injuries in Winter Sports. Physician and Sportsmedicine. 1983;11(1):111-122.

106. Harris JB. First Report of Snowboard Neurological Injury in Winter Sports During a 14-Year Prospective Winter Sports Study. Clinical Sports Medicine. 1989;1(1):45-55.

107. Fukuda O, Endo S. Head Injuries in Skiers and Snowboarders [Japenese]. Japanese Journal of Neurosurgery. 2004;13(2):89-95.

108. Stuart CA, Yau L, Yip R, Brubacher JB, Cripton PA. Understanding Clinical Snow Sport Head Injury and Design of a
Relevant Helmet Testing Apparatus. International Research Council on the Biomechanics of Impact Conference; 2016; Malaga, Spain.

109. Burtscher M, Pühringer R, Werner I, Sommersacher R, Nachbauer W. Predictors of Falls in Downhill Skiing and Snowboarding. 4th International Congress on Science and Skiing, 2007; 2009; St Christoph am Arlberg, Austria.

110. Konik IG, Kermanc MH, Mentis AFA, Germeni E, Petridou E. Fall-Related Head Injuries Among Alpine Skiers and Snowboarders in Slovenia [Abstract]. 10th World Conference on Injury Prevention \& Safety Promotion; 2010; London, England.

111. Philippe M, Ruedl G, Feltus G, Woldrich T, Burtscher M. How Frequent and Why Are Skiers and Snowboarders Falling? [German]. Sportverletzungen Sportschäden. 2014;28(4):188-192.

112. Uzura M, Taguchi Y, Matsuzawa M, Watanabe H, Chiba S Chronic Subdural Haematoma After Snowboard Head Injury. British Journal of Sports Medicine. 2003;37(1):82-83.

113. Lang T, Biedermann H, Röthler G, Daniaux H. Collision Injuries on Ski Slopes [German]. Aktuelle Traumatologie. 1980;10(3):169-177.

114. Lystad H. Collision Injuries in Alpine Skiing. 7th International Symposium on Skiing Trauma and Safety, 1987; 1989; Keystone, CO, USA.

115. Nachbauer W, Burtscher M. Kollisionen auf Schipisten [German]. In: Flora G, ed. Erstversorgung, Bergung und Transport des AIpinen Notfallpatienten. Vol 10. Innsbruck, Austria: International Bergrettungsärztetagung; 1988:39-45.

116. Burtscher M, Philadelphy M. Skiing Collision Accidents: Types of Injuries. 10th International Symposium on Skiing Trauma and Safety,; 1996.

117. Friermood TG, Messner DG, Brugman JL, Brennan R. Save the Trees: A Comparative Review of Skier-Tree Collisions. Journal of Orthopaedic Trauma. 1994;8(2):116-118.

118. Oh S-Y, Nisoli M. Severe Collisions Head Injury in Skiing [German]. Schweizerische Rundschau für Medizin. 1981;70(10):408-413.

119. Médecins de Montagne. L’Accidentologie Générale. Chambéry, France: MDEM;2016.

120. Rice J. Personal Communication. In: Shealy JE, Scher I, Stepan L, Harley E, eds2010.

121. Scher IS, Shealy JE, Stepan L, Thomas R, Hoover R. Terrain Park Jump Design: Would Limiting Equivalent Fall Height Reduce Spine Injuries? 20th International Symposium on Skiing Trauma and Safety, 2013; 2015; Bariloche, Argentina.

122. National Ski Areas Association. Kottke National End of Season Survey for 2010/11. Lakewood, CO, USA: NSAA;2011.

123. Shealy JE, Scher I, Stepan L, Harley E. Jumper Kinematics on Terrain Park Jumps: Relationship Between Takeoff Speed and Distance Traveled. Journal of ASTM International. 2010;7(10):JAI102885.

124. Fukuda O. Head Injuries in Snowboarders [Japanese]. Japanese Journal of Clinical Sports Medicine. 2001;18(11):1245-1249.

125. Henrie M, Petron D, Chen Q, Powell A, Shaskey D, Willick S. Comparison of Ski and Snowboard Injuries that Occur Inside Versus Outside Terrain Parks [Abstract]. 19th International Symposium on Skiing Trauma and Safety, 2011; 2010; Keystone, CO, USA. 
126. Carús L, Escorihuela M. Epidemiology of Feature-Specific Injuries Sustained by Skiers in a Snow Park. Wilderness \& Environmental Medicine. 2016;27(3):415-420.

127. Carús L, Escorihuela M. Feature-Specific Ski Injuries in Snow Parks. Accident Analysis and Prevention. 2016;95(a):86-90.

128. Russell K, Meeuwisse WH, Nettel-Aguirre A, et al. Characteristics of Injuries Sustained by Snowboarders in a Terrain Park. Clinical Journal of Sports Medicine. 2013;23(3):172177.

129. Russell K. The Relationship Between Injuries and Terrain Park Feature Use Among Pediatric and Adult Snowboarders in Alberta [Doctoral Thesis]. Calgary, AB, Canada: Department of Community Health Sciences, University of Calgary; 2011.

130. Dickson TJ, Trathen S, Waddington GS. Speeds of Pediatric Snowsport Participants: Insights for Injury Prevention Strategies. 20th International Symposium on Skiing Trauma and Safety, 2013; 2015; Bariloche, Argentina.

131. Dickson TJ, Trathen S, Waddington GS, Terwiel FA, Baltis D. A Human Factors Approach to Snowsport Safety: Novel Research on Pediatric Participants' Behaviors and Head Injury Risk. Applied Ergonomics. 2016;53(A):79-86.

132. Scher IS, Richards D, Carhart M, Thomas R, Hurlen N, Lam T. Pediatric Head and Neck Injuries in Snow Sports: Evaluating the Influence of Helmets. Journal of ASTM International. 2008;5(4):JAI101400.

133. Shealy JE, Ettlinger CF, Johnson RJ. How Fast Do Winter Sports Participants Travel on Alpine Slopes? Journal of ASTM International. 2005;2(7):JAI12092.

134. Scher IS, Richards D, Carhart M. Head Injury in Snowboarding: Evaluating the Protective Role of Helmets. Journal of ASTM International. 2006;3(4):JAI14203.

135. Ruedl G, Sommersacher R, Woldrich T, Kopp M, Nachbauer W, Burtscher M. Mean Speed of Winter Sport Participants Depending on Various Factors [German]. Sportverletzung Sportschaden. 2010;24(3):150-153.

136. Dickson TJ, Terwiel FA, Waddington GS, Trathen S. Evaluation of the Use of a GPS Data-Logging Device in a Snowsport Environment. 5th Asia-Pacific Congress on Sports Technology; 2011; Melbourne, VIC, Australia.

137. Kendall M, Hoshizaki TB. Comparison between Hybrid III Headforms by Linear and Angular Dynamic Impact Response Characteristics. Journal of ASTM International. 2012;9(4):JAI104270.

138. Ruedl G, Brunner F, Woldrich T, et al. Factors Associated with the Ability to Estimate Actual Speeds in Recreational Alpine Skiers. Wilderness \& Environmental Medicine. 2013;24(2):118-123.

139. Brunner F, Ruedl G, Kopp M, Burtscher M. Factors Associated with the Perception of Speed Among Recreational Skiers. PLoS ONE. 2015;10(6):e0132002.

140. Greenwald RM, Durham S, Beckwith J, Stephens T. Biomechanics of Head Impacts in Pediatric Snowboarders [Abstract]. 18th Congress of the International Society for Skiing Safety; 2009; Garmisch-Partenkirchen, Germany.

141. Dickson TJ, Trathen S, Waddington GS. Investigating Characteristics of Head Impacts in Paediatric Snowsport Participants: Using Telemetry, GPS Positioning and Acceleration Logging. 5th Asia-Pacific Congress on Sports Technology; 2011; Melbourne, VIC, Australia.
142. Dickson TJ, Waddington G, Trathen S, Baltis D, Adams R. Technology Applications to Enhance Understanding of Real-Time Snowsport Head Accelerations. 6th Asia-Pacific Congress on Sports Technology; 2013; Hong Kong, China.

143. Snell Memorial Foundation. Recreational Skiing and Snowboarding. Snell RS-98. North Highlands, CA, USA1998.

144. Snell Memorial Foundation. Skiing and Other Winter Activities. Snell S-98. North Highlands, CA, USA1998.

145. Lissner HR, Lebow M, Evans FG. Experimental Studies on the Relation Between Acceleration and Intracranial Pressure Changes in Man. Surgery, Gynecology \& Obstetrics. 1960;111(3):329-338.

146. Hodgson VR, Thomas LM. Comparison of Head Acceleration Injury Indices in Cadaver Skull Fracture. 15th Stapp Car Crash Conference; 1971; Coronado, CA, USA.

147. McIntosh AS, Kallieris D, Mattern R, Miltner E. Head and Neck Injury Resulting from Low Velocity Direct Impact. 37th Stapp Car Crash Conference; 1993; San Antonio, TX, USA.

148. American Society for Testing and Materials. Standard Specification for Helmets Used for Recreational Snow Sports. ASTM F2040. West Conshohocken, PA, USA2011.

149. Canadian Standards Association. Recreational Alpine Skiing and Snowboarding Helmets. CSA Z263.1. Toronto, ON, Canada2015.

150. European Committee for Standardization. Helmets for Alpine Skiers and Snowboarders. EN 1077. Brussels, Belgium2007.

151. Fédération Internationale de Ski. Specifications for Competition Equipment and Commercial Markings. Crash Helmets. Oberhofen am Thunersee, Switzerland2013.

152. Standards Australia, Standards New Zealand. Protective Helmets for Vehicle Users. AS/NZS 1698. Sydney, NSW, Australia2008.

153. Dressler DM, Richards D, Bates E, Van Toen C, Cripton PA. Head and Neck Injury Potential With and Without Helmets During Head-First Impacts on Snow. 19th International Symposium on Skiing Trauma and Safety, 2011;2012; Keystone, CO, USA.

154. Kleiven S, Halldin P. Investigating the Need for a New Standard/Specification for DH and Super-G Helmets. Stockholm, Sweden: Division of Neuronic Engineering, School of Technology and Health, Royal Institute of Technology;2012.

155. Kleiven S, Halldin P. Head Impact Biomechanics in Ski Related Accident [Abstract]. 4th International Conference on Concussion in Sport; 2013; Zurich, Switzerland.

156. Bailly N, Llari M, Donnadieu T, Masson C, Arnoux P-J. Head Impact in a Snowboarding Accident. Scandinavian Journal of Science \& Medicine in Sports. 2017;27(9):964-974.

157. Post A, Hoshizaki TB, Gilchrist MD, Brien SE, Cusimano MD, Marshall SW. The Influence of Dynamic Response and Brain Deformation Metrics on the Occurrence of Subdural Hematoma in Different Regions of the Brain. Journal of Neurosurgery. 2014a;120(2):453-461.

158. Hajiaghamemar M, Seidi M, Ferguson JR, Caccese V. Measurement of Head Impact Due to Standing Fall in Adults Using Anthropomorphic Test Dummies. Annals of Biomedical Engineering. 2015;43(9):2143-2152. 
159. Seidi M, Hajiaghamemar M, Caccese V. Evaluation of Effective Mass During Head Impact Due to Standing Falls. International Journal of Crashworthiness. 2015;20(2):134-141.

160. Scher IS, Richards D, Carhart M. Head Contact After Catching an Edge: An Examination of Snowboarding Helmets [Abstract]. 16th International Society of Skiing Safety Conference, 2005; 2006; Niigata, Japan.

161. Richards D, Carhart M, Scher IS, Thomas R, Hurlen N. Head Kinematics During Experimental Snowboard Falls Implications for Snow Helmet Standards. Journal of ASTM International. 2008;5(6):JAI101406.

162. Muser MH, Schmitt KU, Lanz C, Walz FH. Experimental Analysis of Biomechanical Loading of Skiing Collisions [German]. Deutsche Zeitschrift für Sportmedizin. 2009;60(10):315-320.

163. McIntosh AS, Patton DA, Fréchède B, Pierré P-A, Ferry E, Barthel T. The Biomechanics of Concussion in Unhelmeted Football Players in Australia: A Case-Control Study. British Medical Journal Open. 2014;4(5):e005078.

164. Petrone N, Tamburlin L, Panizzolo F, Atzori B. Development of an Instrumented Anthropomorphic Dummy for the Study of Impacts and Falls in Skiing. 8th Conference of the International Sports Engineering Association; 2010; Vienna, Austria.

165. Petrone N, Ceolin F, Morandin T. Full Scale Impact Testing of Ski Safety Barriers Using an Instrumented Anthropomorphic Dummy. 8th Conference of the International Sports Engineering Association; 2010; Vienna, Austria.

166. National Operating Committee on Standards for Athletic Equipment. Standard Performance Specification for Newly Manufactured Football Helmets. NOCSAE (ND)00217m19. Overland Park, KS, USA: NOCSAE; 2019.

167. Holbourn AHS. Mechanics of Head Injuries. Lancet. 1943;242(6267):438-441.

168. Gennarelli TA, Thibault LE, Ommaya AK. Comparison of Translational and Rotational Head Motions in Experimental Cerebral Concussion. 15th Stapp Car Crash Conference; 1971; Coronado, CA, USA.
169. Margulies SS, Thibault LE. A Proposed Tolerance Criterion for Diffuse Axonal Injury in Man. Journal of Biomechanics. 1992;25(8):917-923.

170. Shealy JE, Stone F. Tabletop Jumping: Engineering Analysis of Trajectory and Landing Impact. Journal of ASTM International. 2008;5(6):JAI101551.

171. Swearingen JJ, McFadden EB, Garner JD, Blethrow JG. Human Tolerance to Vertical Impact. Aerospace Medicine Association Meeting; 1960; Miami, FL, USA.

172. Müller E. Biomechanics of Ski Jumping - Scientific Jumping Hill Design. 1st International Congress on Science and Skiing, 1996; 1997; Austria.

173. Hubbard M. Safer Ski Jump Landing Surface Design Limits Normal Impact Velocity. Journal of ASTM International. 2009;6(1):JAI101630.

174. McNeil JA. Modeling the "Pop" in Winter Terrain Park Jumps. 19th International Symposium on Skiing Trauma and Safety, 2011; 2012a; Keystone, CO, USA.

175. McNeil JA, McNeil JB. Dynamical Analysis of Winter Terrain Park Jumps. Sports Engineering. 2009;11(3):159-164.

176. McNeil JA. The Inverting Effect of Curvature in Winter Terrain Park Jump Takeoffs. 19th International Symposium on Skiing Trauma and Safety, 2011; 2012b; Keystone, CO, USA.

177. Depreitere B, Van Lierde C, Verschueren P, et al. Cerebral Bridging Vein Rupture in Humans. IUTAM Symposium on Impact Biomechanics: From Fundamental Insights to Applications Solid Mechanics and Its Applications; 2005; Dublin, Ireland.

178. Fijalkowski RJ, Stemper BD, Pintar FA, Yoganandan N, Gennarelli TA. Determination of Diffuse Brain Injury Thresholds Using Retrospective Analysis [Extended Abstract]. Summer Bioengineering Conference; 2007a; Keystone, CO, USA.

179. National Institute for Occupational Safety and Health. Heirarchy of Controls. Atlanta, GA, USA: CDC;2015.

180. Padulo J, Oliva F, Frizziero A, Maffulli N. Muscles, Ligaments and Tendons Journal - Basic principles and recommendations in clinical and field Science Research: 2018 update. MLTJ 2018; 8(3): 305 - 307. 